\title{
ISTÁLLÓSKŐ REVISITED: LITHIC ARTEFACTS AND ASSEMBLAGES, SIXTY YEARS AFTER
}

\author{
ANDRÁS MARKÓ \\ Hungarian National Museum \\ 14-16 Múzeum krt., H-1088 Budapest, Hungary \\ E-mail: markoa@hnm.hu
}

\begin{abstract}
The Istállóskő cave, one of the classical sites in Hungary was generally regarded as the only important locality of the Aurignacian culture with two discrete culture-bearing layers. The assemblages played a key role in several theories on the appearance of the Upper Palaeolithic in Europe; however, this is the first time that all the lithic artefacts found since 1912 until 1965 are studied in details.

As a result of our analysis, none of the studied lithic assemblages could be attributed to to the $s$. str. Aurignacian industry as the diagnostic pieces are absent. Quite atypical fragmented blades and a bifacial tool have been uncovered in the poor 'lower (Aurignacian I) culture-bearing layer', which - together with the rich osseous industry, including split based points - are compared to the assemblages of the Jankovich cave (Transdanubia), the Dzeravá skála/Pálffy cave (Slovakia) and layer G1 in the Vindija cave (Croatia). In the 'upper (Aurignacian II) culture-bearing layer' the few Mladeč/Olschewa-type osseous artefacts were associated with Gravettian flint lithics and Middle Palaeolithic and bifacial elements made from radiolarite and felsitic porphyry. This industry is compared to those known from early Gravettian sites and the Szeleta cave.
\end{abstract}

Keywords: Aurignacian, leaf shaped implements, refitting, taphonomy, flint

The Istállóskő cave in the western part of the Bükk Mountains (north-eastern Hungary) was considered for a long time as the only important Aurignacian locality in Hungary, which was explored by numerous excavations (Table $1^{1}$ ) and discussed in countless preliminary reports ${ }^{2}$ and synthetic works. ${ }^{3}$ The results of the last large-scale excavations were published in a monograph of pioneering importance in volume 5 of Acta Archaeologica Hungarica $^{4}$ and since then, the site has been mentioned in several articles dealing with the Palaeolithic period of the Carpathian Basin $^{5}$ or the Aurignacian industry. ${ }^{6}$ However, despite the recent systematic revision of the archaeological material, ${ }^{7}$ this is the first time that all the lithic artefacts found in the cave since $1912^{8}$ are studied, with the exception of the unpublished pieces from the excavations of the Miskolc University. ${ }^{9}$

${ }^{1}$ For the details see: VöRös 2003-2004; Mester 2007.

${ }^{2}$ Hillebrand 1913, 21-23, 48-49; Hillebrand 1914; Hillebrand 1917, 106-108, 129-130; Hillebrand 1919, 10-13, 41; HILLEBRAND 1926, 5; KADIĆ 1915a, 17; SAÁD 1927; 1929; MоTTL 1945, 1535-1543; VÉRTES 1951.

${ }^{3}$ Kadić 1934, 74-77; Hillebrand 1919b; Hillebrand 1934/35, 19-20; Hillebrand 1935, 14-15; MotTl 1942, 82-93; Kadić-MotTL 1944, 33-54.

${ }^{4}$ e.g. VÉRTES 1955; JÁNOSSY 1955.

${ }^{5}$ VÉRTES 1956a, 16-17; VÉRTES 1965, 164-165; GÁBORI 1964, 9-11; GÁBORI 1969, 160; Dobosi 1975; SvOBODA-SimÁn 1989, 310-313; AdAms 1998, 41-44; AdAMs 2007, 94; SimÁN 2006; KoZŁowsKi et al. 2009, 402-403.
${ }^{6}$ E.g. Laplace 1970, 278; BÁNesz 1976, 62-64; HahN 1977, 121-123.

7 AdAMs 2002; Dobosi 2002; Ringer 2002; VÖRÖS 2003 2004; ADAMS-Ringer 2004; MESTER 2007.

${ }^{8}$ L. Vértes, G. Laplace and J. Hahn worked only with the find material of the last excavations; B. Adams had the opportunity to examine 418 pieces: VÉRTES 1955; LAPLACE 1970, 278; HAHN 1977, 122-123; ADAMs 1998, 43. - We would like to express our thanks for the help of our colleagues Péter Szolyák and György Kalászdy (Herman Ottó Museum, Miskolc).

${ }^{9}$ ADAMS 2007. 
Table 1. Istállóskő cave, history of the excavations in the cave, 1911/1912-1965

\begin{tabular}{|c|c|c|c|c|}
\hline date & leader & cave section & feature & artefacts \\
\hline 1912 (1911?) & J. Hillebrand & & hearth $(-40-80 \mathrm{~cm})$ & $?$ \\
\hline August 1913 & J. Hillebrand & middle section & hearth $(-80 \mathrm{~cm})$ & 50 lithics \\
\hline 9-19. 07. 1914 & J. Hillebrand & middle section & hearth & 'many lithics' \\
\hline $19-2608.1916$ & J. Hillebrand & middle section & hearth & 26 lithics, 2 bone tools \\
\hline 21-29. 08. 1917 & J. Hillebrand & middle section & hearth & 49 lithics, 2 bone tools \\
\hline \multirow[t]{2}{*}{ October 1925} & J. Hillebrand & middle section & hearth & 16 lithics \\
\hline & & back section & hearth & $?$ \\
\hline \multirow[t]{2}{*}{1927} & A. Saád - G. Megay & back section & upper hearth, $-200 \mathrm{~cm}$ & Gravettian tools, atypical blades \\
\hline & & & lower hearth, $-220 \mathrm{~cm}$ & 2 bone tools \\
\hline $22.10-13.11 .1929$ & O. Kadić & $?$ & $?$ & ? 'Magdalenian'? \\
\hline \multirow[t]{3}{*}{$23.07-06.09 .1938$} & M. Mottl & southern section & hearth & no artefacts? \\
\hline & & middle section & & $?$ \\
\hline & & back section & & ? five bone artefacts \\
\hline \multirow[t]{3}{*}{07.1947} & L. Vértes & at the NE wall & hearth & Gravettian lithics (25 pieces) \\
\hline & & front section & & \\
\hline & & end of the cave & 'skull deposition' & 5 lithics \\
\hline 1948 & L. Vértes & entrance & & 3 'Magdalenian' tools \\
\hline 1950 & L. Vértes & front and middle section & 2 culture-bearing layers & \\
\hline 1951 & L. Vértes & front and middle section & 2 culture-bearing layers & \\
\hline 10.08 .1952 & L. Vértes & middle section & $?$ & $?$ \\
\hline 1958 & L. Vértes & middle section & lower hearth-level & leaf-shaped scraper \\
\hline 10.08 .1965 & L. Vértes & & lower culture-bearing layer & \\
\hline
\end{tabular}

Table 2. An attempt to identify the Pleistocene layers in the Istállóskő cave

\begin{tabular}{|c|c|c|c|c|}
\hline VÉRTES 1951 & VÉRTES 1955 & VÖRÖs 1986 & RINGER 2002 & VöRÖS 2003-2004 \\
\hline $\begin{array}{l}\text { b: grainy Magdalenian } \\
\text { clay (in front of the cave) }\end{array}$ & 2: light yellow clay & $\begin{array}{l}\text { VI: light yellow clay } \\
\text { ('upper microfaunal } \\
\text { layer') }\end{array}$ & $\begin{array}{l}\text { c: cave loess with } \\
\text { limestone debris }\end{array}$ & $\begin{array}{l}\text { upper level: } \\
\text { 'upper microfaunal layer' }\end{array}$ \\
\hline $\begin{array}{l}\text { c: yellow clay with stones } \\
\text { ('Magdalenian') }\end{array}$ & 3: yellow clay with stones & V: yellow clay & & 1: yellow loessic clay \\
\hline \multirow{2}{*}{$\begin{array}{l}\text { d: greyish yellow sterile } \\
\text { clay }\end{array}$} & 4: sterile, yellow clay & & & \\
\hline & $\begin{array}{l}\text { 7: yellowish brown loessy } \\
\text { layer }\end{array}$ & $\begin{array}{l}\text { IV: yellowish brown } \\
\text { loessy clay (large hearth) }\end{array}$ & & 2: yellowish brown layer \\
\hline \multicolumn{5}{|l|}{$\begin{array}{l}\text { e: cemented yellow clay } \\
\text { (in front of the cave) }\end{array}$} \\
\hline $\begin{array}{l}\text { f: warm brown stony clay } \\
{[=f / a]}\end{array}$ & $\begin{array}{l}\text { 8: dark brown clay with } \\
\text { stones }\end{array}$ & $\begin{array}{l}\text { III: sedimentary } \\
\text { complex ('Upper cul- } \\
\text { ture-bearing layer' with } \\
3 \text { culture-bearing levels) }\end{array}$ & $\begin{array}{l}\text { d, e, g?: interstadial cave } \\
\text { soils and } \\
\text { H: hearths: Arcy-Stillfried } \\
\text { B, Les Cottés interstadials }\end{array}$ & 3: dark brown clay \\
\hline \multirow[t]{3}{*}{$\begin{array}{l}\text { g: dark brown 'lower } \\
\text { microfaunal layer' }\end{array}$} & $\begin{array}{l}\text { 5: dark brown with } \\
\text { microfauna }\end{array}$ & II: dark brown layer & & \\
\hline & 11: grey debris & & & \\
\hline & 12: reddish inclusion & & & \\
\hline$[\mathrm{f} / \mathrm{b}]:$ & 9: pale brown clay & $\begin{array}{l}\text { I: light brown clay } \\
\text { ('Lower culture-bearing } \\
\text { layer' with two culture- } \\
\text { bearing levels) }\end{array}$ & $\begin{array}{l}\text { g?, i: interstadial cave } \\
\text { soil(s): Hengelo } \\
\text { interstadial and } \\
\text { h: cave loess with } \\
\text { limestone debris }\end{array}$ & 4: light brow clay \\
\hline h, i & $\begin{array}{l}10: \text { in situ weathered } \\
\text { mother rock }\end{array}$ & & $\begin{array}{l}\mathrm{j}, \mathrm{k}, \mathrm{l} \text { : cave soil } \\
\text { (Moershoofd) and loess }\end{array}$ & $\begin{array}{l}\text { 5: layers with various } \\
\text { colours }\end{array}$ \\
\hline
\end{tabular}


Table 3. The raw material composition of the assemblages

\begin{tabular}{|c|c|c|c|c|c|c|c|c|c|c|c|c|}
\hline & \multicolumn{2}{|c|}{ Hillebrand } & \multirow{2}{*}{$\begin{array}{c}\text { Saád } \\
13\end{array}$} & \multirow{2}{*}{$\begin{array}{c}\text { Mottl } \\
11\end{array}$} & \multirow{2}{*}{$\begin{array}{c}\begin{array}{c}\text { Vértes } \\
\text { rear } \\
\text { section }\end{array} \\
2\end{array}$} & \multirow{2}{*}{$\begin{array}{c}\begin{array}{c}\text { Vértes } \\
\text { large } \\
\text { fireplace }\end{array} \\
10\end{array}$} & \multirow{2}{*}{$\begin{array}{c}\text { Vértes } \\
\text { 'Magda- } \\
\text { lenian' } \\
5\end{array}$} & \multirow{2}{*}{$\begin{array}{c}\text { lower } \\
\text { layer }\end{array}$} & \multicolumn{2}{|c|}{ upper layer } & \multicolumn{2}{|c|}{ total } \\
\hline flint & 191 & $84.14 \%$ & & & & & & & 28 & $28.00 \%$ & 268 & $61.61 \%$ \\
\hline limnic quartzite & 10 & $4.41 \%$ & 2 & 2 & 1 & 1 & 1 & 12 & 41 & $41.00 \%$ & 70 & $16.09 \%$ \\
\hline lydite & 11 & $4.85 \%$ & 2 & 1 & & 1 & & 2 & 6 & $6.00 \%$ & 27 & $6.21 \%$ \\
\hline radiolarite & 5 & $2.20 \%$ & & & & 1 & 4 & 6 & 10 & $10.00 \%$ & 28 & $6.44 \%$ \\
\hline obsidian & & & 1 & 1 & & & & 3 & 3 & $3.00 \%$ & 8 & $1.84 \%$ \\
\hline felsitic porphyry & 2 & $0.88 \%$ & & & & & 1 & 3 & 3 & $3.00 \%$ & 9 & $2.07 \%$ \\
\hline quartzite & & & 1 & & & & & 1 & 6 & $6.00 \%$ & 8 & $1.84 \%$ \\
\hline others & 3 & $1.32 \%$ & & 2 & & & & & 2 & $2.00 \%$ & 7 & $1.61 \%$ \\
\hline burned flint & 5 & $2.20 \%$ & & & 1 & 2 & & 1 & 1 & $1.00 \%$ & 10 & $2.30 \%$ \\
\hline & 227 & $100.00 \%$ & 19 & 17 & 4 & 15 & 11 & 38 & 100 & $100.00 \%$ & 435 & $100.00 \%$ \\
\hline
\end{tabular}

Originally, we studied the raw material use of the Istállóskő assemblages (Table 3) within the frames of the Middle/Upper Palaeolithic transition and the appearance of the Upper Palaeolithic industries. Later, during the overview of the 'early' osseous artefacts from Transdanubia, we recognised that these antler and ivory tools, including split based points are never associated with Aurignacian-type lithics in south-eastern Europe. ${ }^{10}$ As the Istállóskő cave yielded one of the largest collections of this group of artefacts in Central Europe, it seemed to be intriguing to test this hypothesis by investigating the lithics from this site. Next a systematic refitting program was carried out to detect certain aspects points of site formation and behavioural patterns. Although these studies may face serious problems when applied to old excavation materials when the sediment was recovered by picks and transported by trucks to the sunlight for collecting artefacts and fossil bones a relatively high number of refit groups could be determined in the Istállóskő assemblages (Table 4), some of them first recognised by László Vértes. ${ }^{11}$ The majority of the groups are reconstructions of natural breaks (sometimes as a consequence of relatively recent events, possibly during the excavations, e.g. group 14) but three reduction refits (group 6,15 and 17) have also been identified.

Many doubts have been formulated about the value of the field documentations since the fifties and during our analysis we have also realised heavy inconsistencies in the details of the excavations. Some of them, like the date of the first excavations, the place and the dimensions of the trenches, the colour, designation and identification of the certain lithostratigraphical units, the relative depth and the dimensions of the 'lower hearth layer' etc. were recently taken into account in a study by István Vörös. ${ }^{12}$ Concerning the accurate provenance data of the artefacts the general problem was the supposed lack of the original field documentations. ${ }^{13}$ However, the detailed description of the field works, numerous sketches and drawings of the trenches and the sections, and finally the lists ${ }^{14}$ of the excavated pieces are available at least in the case of the excavations by Vértes. ${ }^{15}$ That is why we will mainly focus on the assemblages of the last excavations in the followings and determine the original planigraphical and stratigraphic position of the artefacts with the use all of these documentations. ${ }^{16}$

${ }^{10}$ MARKó 2011; MARKó 2013.

${ }^{11}$ Refit group 2, see: VéRTES 1955: Tab. XLIX. 7.

12 VÖRÖS 2003-2004.

${ }^{13}$ E.g. Ringer 2002, 51

${ }^{14}$ In these lists the individual identity number of the given piece, the trench, the lithostratigraphic unit and the depth (measured from a datum point) of its finding place, moreover the date of the documentation and the raw material of each artefact were indicated. The pieces found in trench VIII, excavated by micro-stratigraphic methods, are exceptions as the height measured above the mother rock was recorded instead of the depth. (see Table 4)
${ }^{15}$ Kept in the archives of the Hungarian National Museum under the number of 51.B.1, 2.U.I and 30.I.I. The documentation of the 1950 season was earlier also used by DoBosi 2002, VöRÖs 2003 2004, and DAVIES and Hedges 2011. - Regrettably, data are missing from the period of 17-12 September 1950, when a leaf-shaped fragment and elements of refit groups 3 and 9 were collected in block IV.

${ }^{16}$ We have to keep in mind, however, that at least the list of the artefacts was compiled after the end of the seasons, as it was general in almost all the old key sites in Hungary: MESTER 2001, fn. 4. 
Table 4. Lithic refit groups in the Istállóskő cave

\begin{tabular}{|c|c|c|c|c|c|c|}
\hline & inv. nr. & excavation, trench, layer, depth ${ }^{17}$ & & & raw material & \\
\hline 1 & $27 / 1917.24$ & Hillebrand 1917 & \multirow{2}{*}{$\begin{array}{l}\text { fragments } \\
\text { of a retouched blade }\end{array}$} & asymmetric patina & flint & \\
\hline & 27/1917.33 & Hillebrand 1917 & & & & \\
\hline \multirow[t]{2}{*}{2} & $\mathrm{~Pb} .51 / 6$ & Vértes 1951 , trench X, layer III, $-1.3 \mathrm{~m}$ & \multirow{2}{*}{$\begin{array}{l}\text { fragments } \\
\text { of a retouched blade }\end{array}$} & & limnic quartzite & \\
\hline & $\mathrm{Pb} .51 / 9$ & Vértes 1951, trench X, layer III, -1.3 m & & & & \\
\hline \multirow[t]{2}{*}{3} & $44 / 1918.1$ & Hillebrand, 1912-1917 & \multirow[t]{2}{*}{ blade fragments } & \multirow{2}{*}{$\begin{array}{l}\text { patinated surface, } \\
\text { worked after frac- } \\
\text { ture }\end{array}$} & & Fig. 5.3 \\
\hline & Pb. $50 / 148$ & Vértes, 1950 trench IV? & & & & \\
\hline \multirow[t]{2}{*}{4} & $42 / 1916.12$ & Hillebrand, 1916 & \multirow[t]{2}{*}{ core fragments } & \multirow{2}{*}{$\begin{array}{l}\text { patinated surface, } \\
\text { fracture because of } \\
\text { inhomogeneity }\end{array}$} & flint & Fig. 1, 2.2 \\
\hline & $44 / 1918.4$ & Hillebrand, 1912-1917 & & & & \\
\hline \multirow[t]{2}{*}{5} & Pb. $871[73]$ & Hillebrand, 1912-1914 & \multirow[t]{2}{*}{ blade fragments } & \multirow{2}{*}{$\begin{array}{l}\text { broken artefact } \\
\text { with differently } \\
\text { patinated } \\
\text { fragments }\end{array}$} & flint & \\
\hline & $\mathrm{Pb} .872[72]$ & Hillebrand, 1912-1914 & & & & \\
\hline \multirow[t]{2}{*}{6} & $\mathrm{~Pb} .1708[1]$ & Mottl 1938 & \multirow[t]{2}{*}{ two blades } & reduction refit & limnic quartzite & \\
\hline & Pb. $1708[1]$ & Mottl 1938 & & & & \\
\hline \multirow[t]{2}{*}{7} & $\mathrm{~Pb} .51 / 18$ & Vértes 1951, trench VIII, layer III, $1,3 \mathrm{~m}$ & \multirow{2}{*}{$\begin{array}{l}\text { fragments } \\
\text { of a retouched blade }\end{array}$} & \multirow[t]{2}{*}{ old fragments } & & Fig 7.2 \\
\hline & $\mathrm{Pb} .51 / 63$ & Vértes 1951 , trench VIII, layer III, 0,9 m & & & & \\
\hline \multirow[t]{3}{*}{8} & Pb. 50/70 [106] & Vértes 1950 , trench VI, $-1,1-1,4 \mathrm{~m}$ & \multirow{3}{*}{$\begin{array}{l}\text { fragments of a } \\
\text { cortical blade }\end{array}$} & & radiolarite & Fig. 10.1 \\
\hline & Pb. 50/80 [39] & $\begin{array}{l}\text { Vértes 1950, trench I, level III of the } \\
\text { layer „f” }\end{array}$ & & & & \\
\hline & Pb. $50 / 145$ & Vértes 1950 , from the refuse material & & & & \\
\hline \multirow[t]{2}{*}{9} & Pb. 50/149 & Vértes 1950, trench IV? & \multirow[t]{2}{*}{ blade fragments } & patinated surface & & \\
\hline & $\mathrm{Pb} .51 / 5$ & Vértes 1951, trench IX, layer III, $-1,3 \mathrm{~m}$ & & & & \\
\hline \multirow[t]{2}{*}{10} & 27/1917.17 & Hillebrand 1917 & & \multirow{2}{*}{$\begin{array}{l}\text { patinated surface, } \\
\text { worked after the } \\
\text { fracture }\end{array}$} & & Fig. 4.8 \\
\hline & $\mathrm{Pb} .50 / 121[113]$ & Vértes 1950, trench V, 'upper hearth' & & & & \\
\hline \multirow[t]{2}{*}{11} & $\mathrm{~Pb} .50 / 108$ & Vértes 1950 & & \multirow{2}{*}{$\begin{array}{l}\text { not patinated } \\
\text { surfaces }\end{array}$} & & \\
\hline & Pb. 50/144 & Vértes 1950 & & & & \\
\hline \multirow[t]{3}{*}{12} & Pb. 51/37 & $\begin{array}{l}\text { Vértes 1951, trench VIII, upper level of } \\
\text { layer III, } 1,35-1,55 \mathrm{~m}\end{array}$ & fragments & \multirow[t]{2}{*}{$\begin{array}{l}\text { not patinated } \\
\text { surfaces }\end{array}$} & & \\
\hline & Pb. $51 / 42$ & $\begin{array}{l}\text { Vértes 1951, trench VIII, upper level of } \\
\text { layer III, } 1,35-1,55 \mathrm{~m}\end{array}$ & & & & \\
\hline & Pb. 51/66 & $\begin{array}{l}\text { Vértes 1951, trench VIII, upper level of } \\
\text { layer III }\end{array}$ & & & & \\
\hline 13 & Pb. $51 / 8$ & $\begin{array}{l}\text { Vértes } 1951, \text { trench } \mathrm{X}, \mathrm{III} ? \\
\text { (I? mixed layer?) }-1,3 \mathrm{~m} \\
\end{array}$ & blade fragments & & & Fig. 7.3 \\
\hline & $\mathrm{Pb} .51 / 76$ & Vértes 1951, trench VIII, layer III, $1,3 \mathrm{~m}$ & & & & \\
\hline 14 & Pb. 50/178 & Vértes 1950, 'lower layer' & blade fragments & recent damage & & \\
\hline & Pb. 50/183 & Vértes 1950, 'lower layer' & & $\begin{array}{l}\text { (during } \\
\text { excavations?) }\end{array}$ & & \\
\hline 15 & $\mathrm{~Pb} 544$ & Hillebrand 1912-1914 & core, chip and blade & & flint & Fig. 2.1 \\
\hline & Pb. $872[98]$ & Hillebrand 1912-1914 & & preparation & & \\
\hline & $27 / 917.2$ & Hillebrand 1917 & & & & \\
\hline 16 & Pb. 51/44 & $\begin{array}{l}\text { Vértes 1951, trench X layer e(?) : loose, } \\
\text { loessic layer }\end{array}$ & blade-like flake & fracture & limnic quartzite & Fig. 7.1 \\
\hline & $\mathrm{Pb} .51 / 31$ & Vértes 1951 , trench VIII, $1,3 \mathrm{~m}$ & & & & \\
\hline 17 & $\mathrm{~Pb} .50 / 112$ [4] & $\begin{array}{l}\text { Vértes } 1950 \text {, trench III, }-1,3 \mathrm{~m} \text { (at the } \\
\text { border of layers IV and III, } \\
\text { at the wall of the cave) }\end{array}$ & core & $\begin{array}{l}\text { during } \\
\text { preparation? } \\
\text { Inhomogeneity? }\end{array}$ & limnic quartzite & Fig. 7.4 \\
\hline & Pb. 50/135 [82] & Vértes 1950 & flake / fragment & & & \\
\hline
\end{tabular}

${ }^{17}$ In the case of trench VIII the data are given according to the height measured above a zero point (in italics), see note 15. 
In this work we use the stratigraphic reconstruction by I. Vörös: six Pleistocene lithological units and numerous gaps in the infilling. ${ }^{18}$ According to this work the light brown layer I and the reddish brown layer III yielded the artefacts of the lower and the upper culture-bearing levels, while layers IV and V are described as yellowish brown and yellow loessy clay. Finally, the lens-like sedimentary units II and VI and a not specified unit overlying the 'Upper culture-bearing layer' and designed as layer $e$ in 1951 were characterised by a rich micromammal material.

Many distinct lithological subunits (e.g. dark brown bands of clay, 'deposited in calm water', yellow level in the upper part of the yellowish brown layer in some 'dry places' ${ }^{19}$ or the mentioned 'loose loessic layer' yielding the proximal fragment of a limnic quartzite blade of refit group 16: Fig. 7.1) were mentioned from the cave in the descriptions of the last hundred years which cannot be compared with the layers identified by Vörös. This fact well illustrates the general problems with the stratigraphy and the exact correlation of the different sections in the cave, ${ }^{20}$ and accordingly, the data of Table 2 about the correlation of the stratigraphic units of different authors should be used with reservations.

\section{LITHIC RAW MATERIALS (Table 3)}

Jenő Hillebrand identified the rock used in the cave as flint, ${ }^{21}$ while Mária Mottl ${ }^{22}$ determined the largest part of the assemblage as white or whitish blue chalcedony and chalcedony-opal. In the 1970s, Janusz Krzysztof Kozłowski ${ }^{23}$ placed the source of this characteristic raw material to the Dniester basin and 15 years later Brian Adams used UV light to differentiate the different flint types (basically from the Prut valley and Polish variants). ${ }^{24}$ Finally, Katalin Simán ${ }^{25}$ supposed the geological source of the 'soapy homogenous silex', making up $65 \%$ of the assemblage of the upper layer, in northern part of the Carpathian Basin.

Originally we distinguished 19 different macroscopic 'flint' variants based on the differences of the colour and the matrix of the rock and the cortex. Some pieces could be compared to the geological samples of Volhynian or Dniester-type ${ }^{26}$ and Chocolate flint, but the weathered (i.e. patinated) surface and the lack of cortex on the majority of the artefacts did not allow the macroscopic identification of either the type or the source area of the rocks. Nevertheless, we found pieces of similar or seemingly identical raw material in an archaeological context in the 'Aurignacian' locality of the nearby Peskő cave, in the early Gravettian assemblage of Bodrogkeresztúr-Henye and in Copper Age graves.

As our refit groups 4 and 5, in which the fragments of the same piece were sorted into different raw material groups, indicate that the appearance of patination may also be misleading and our repeated luminescence experiments have merely demonstrated differences in the degree of the weathering and not in the petrography or the provenance of the given fragments (Fig. 1). Finally, the neutron-physical examinations of the geological and archaeological flint samples ${ }^{27}$ did not yield any reassuring results. That is why in this study we use the term 'flint' simply for the high quality siliceous rocks, at least partly with a source area lying outside the Carpathians, but in accordance with the views of Simán, possibly including silex and excellent quality limnic quartzite variants ${ }^{28}$ from the mid-mountains in northern Hungary and Slovakia too. In general, further examinations are necessary to detect the role of these rocks, which were imported, at least in some cases from 225 or even 490-500 km (from the region of Krakow and the Prut valley); it may also be suggested that erratic, Chocolate-type and Jurassic flint types could also be collected from moraine outcrops in Little Poland. ${ }^{29}$

${ }^{18}$ VÖRÖs 1984, 7-9. - Although this author recently outlined another possible reconstruction for the layer sequence, in the practice he used the system developed in the 1980s (VöRös 2003-2004).

${ }^{19}$ MotTl 1942, 82-84; MotTl 1945, 1536-1538.

${ }^{20}$ The layer sequence published by Vörös (1984, Fig. 1) and Ringer (2002, Fig 2B) are different in many points too.

${ }^{21}$ Hillebrand 1935 - with reference to the geologist $\mathrm{S}$.

\footnotetext{
${ }^{22}$ Mottl 1942, 86; Kadić-Mottl 1944, 53.

${ }^{23}$ KozŁowsKi 1973, 8, 10

${ }^{24}$ AdAMs 1998, 92-93, Table 6.4-5.

25 SimÁn 2006, 455. - c.f. SvobodA-SimÁn 1989, 313.

${ }^{26}$ E.g.: Inv. nr: L. 86/218 in: BIRÓ-DoBOSI 1991.

${ }^{27}$ KASZTOvsZKY et al. 2008.

${ }^{28}$ See: BIRÓ 1998,51 , note 18.

${ }^{29}$ WILCZYÑSKI 2009, 101.
} 

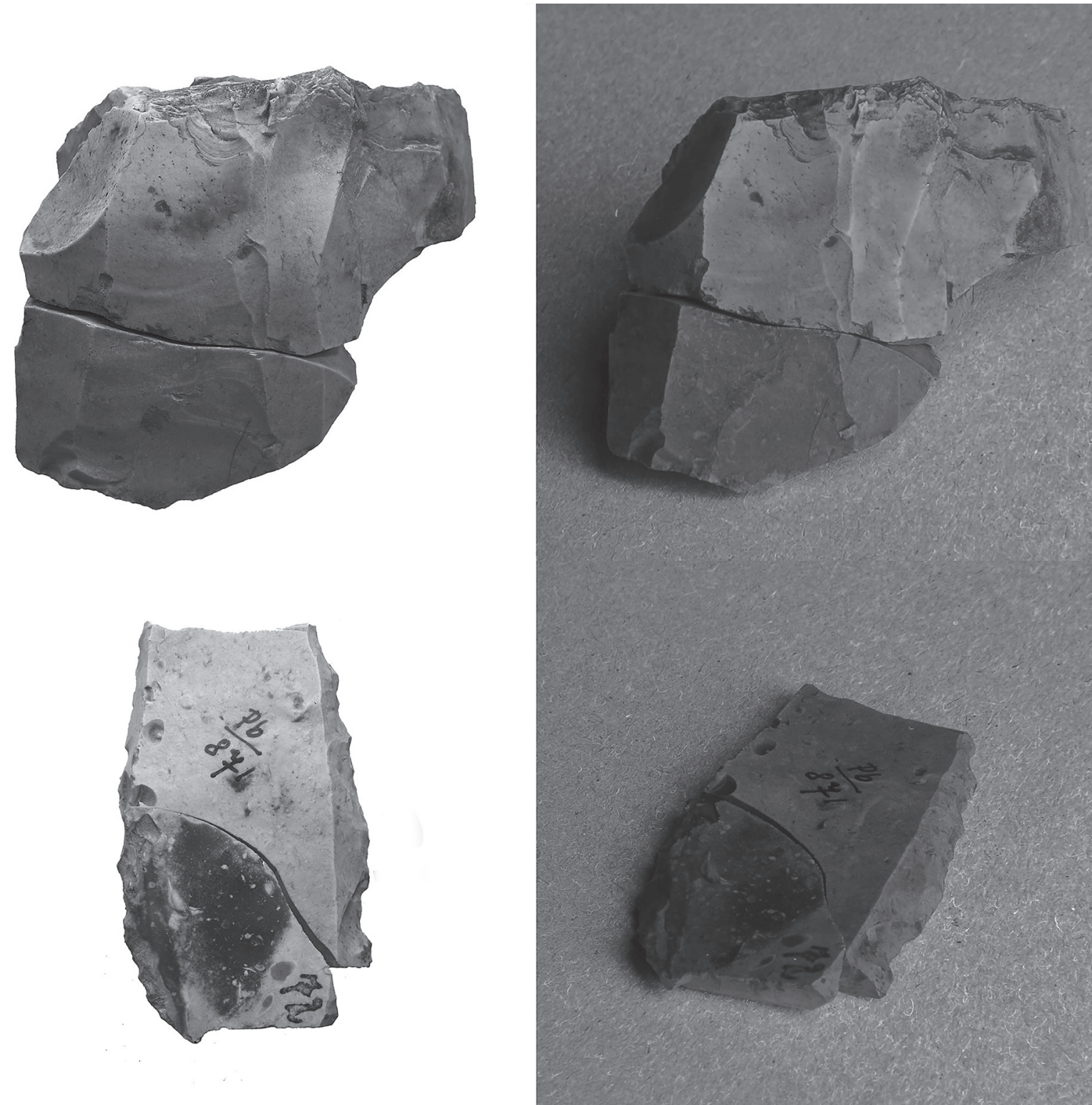

Fig. 1. Variations in patina formation: refit groups 4 and 5 under normal and UV light (photo: A. Dabasi, Cs. Gulyás, HNM)

The limnic quartzite (also called as limnosilicite) variants are common and colourful postvolcanic siliceous rocks of the Neogene volcanic ranges in northern Hungary and Slovakia. There are relatively well-known outcrops of this raw material at the foothills of the Bükk Mountains (e.g. on the Avas hill in Miskolc ${ }^{30}$ ), which, however, were seemingly not used in the Istállóskő cave. Huge sources with workshop materials have been reported from the Tokaj-Prešov hills, ${ }^{31}$ from where the Korlát variant is the dominating raw material at the Aurignacian sites of the Košice basin ${ }^{32}$ and some pieces from the Istállóskő cave belong to this type, imported to the site from a distance of $68 \mathrm{~km}$. However, the source area of the majority of the patinated pieces cannot be identified securely enough.

30 TAKÁCS-BIRÓ 1986, 191.

${ }^{31}$ TAKÁCS-BIRÓ 1986, 191-194; KAMINSKÁ 1991, 20.

${ }^{32}$ Originally identified as 'hornstone', recently as Arkatype hydroquartzite: KAMINSKÁ 1991, 8-10, 30-31. - The siliceous rocks of a hydrothermal origin were popular at other 'Aurignacian' and Gravettian sites (e.g. Acsa and Püspökhatvan where the majority of the artefacts were made of locally available limnic quartzite: DoBOSI 2008). 
There are several possible primary sources of the radiolarite in the Mesozoic formations of the Bükk Mountains, ${ }^{33}$ at Darnó hill ${ }^{34}$ lying at the northern edge of the Mátra Mountains and in the Carpathians. ${ }^{35}$ The rock used at the Eastern Slovakian Aurignacian sites belongs to this latter variant and its provenance is linked to the alluvia of the Torysa and Hornád/Hernád rivers. ${ }^{36}$ In the Istállóskő assemblages a total of seven macroscopic variants have been identified; the presence of pebble cortex on some artefacts shows that pieces were also collected from secondary deposits, probably also from the Hernád valley or from old pebble formations.

The black coloured rock containing radiolaria skeletons in a rock-forming quantity is traditionally called lydite. Outcrops of this raw material are known from the Silurian, Devonian and Carboniferous formations of the Uppony hills ${ }^{37}$ lying $20 \mathrm{~km}$ from the cave.

Felsitic porphyry (earlier quartz porphyry, most recently metarhyolite), which has a single geological source area in the vicinity of Miskolc at a distance of $16-18 \mathrm{~km}$ from the site, was the favourite rock type of the Szeleta cave, however, in certain periods it was also transported to some hundreds of kilometres. ${ }^{38}$

All the classical variants of the obsidian are represented by a low number in the assemblages of the Istállóskő cave. The actually known geological sources of obsidian are lying 69-106 km from the site in the vicinity of Mád, Erdőbénye and Tolcsva in Hungary, and Viničky, Streda nad Bodrogom and in the Zemplén/Zemplín island mountains (Vel'ka and Malá Bara) in Slovakia.

Vein quartzite is a common rock type in the vicinity of the site, but it is mostly represented by unmodified pebble fragments in the cave sediment which possibly do not belong to the archaeological material. We have to mention burned silex, which is represented by surprisingly few pieces, at least compared to the high number and large dimensions of the 'hearths', unearthed in every layer of the cave. ${ }^{39}$ Finally, the local crystalline limestone, andesite and wooden opal are represented by single pieces in the archaeological assemblages.

\section{THE EXCAVATIONS, OBSERVATIONS AND LITHIC ARTEFACTS}

During the 1910s J. Hillebrand excavated 40 square meters ${ }^{40}$ of a single 'hearth layer' in the lower part of the yellow clay (layer IV) and at the border of the underlying reddish brown clay (layer III). ${ }^{41}$ The 'palaeoliths' were mainly documented in this hearth, ${ }^{42}$ however, some pieces were found above and below this level and in disturbed places too. The artefacts were dispersed into three collections: in the Geological Institute, the National Museum in Budapest and the Miskolc Museum. ${ }^{43}$ In the flint-dominated assemblage of the five seasons (1912-1917), there are two bipolar (Fig. 2.2) and three unipolar blade cores (one of them from burned flint) and an irregular piece with numerous prepared striking platforms possibly belongs to a non-Palaeolithic occupation. A preparation flake and a blade were joined to a double platform core, which shows on-site blade production (refit group 15: Fig. 2.1). Besides, there are 11 crested blades (one of them from lyddite, four of them are atypical pieces) in the assemblage.

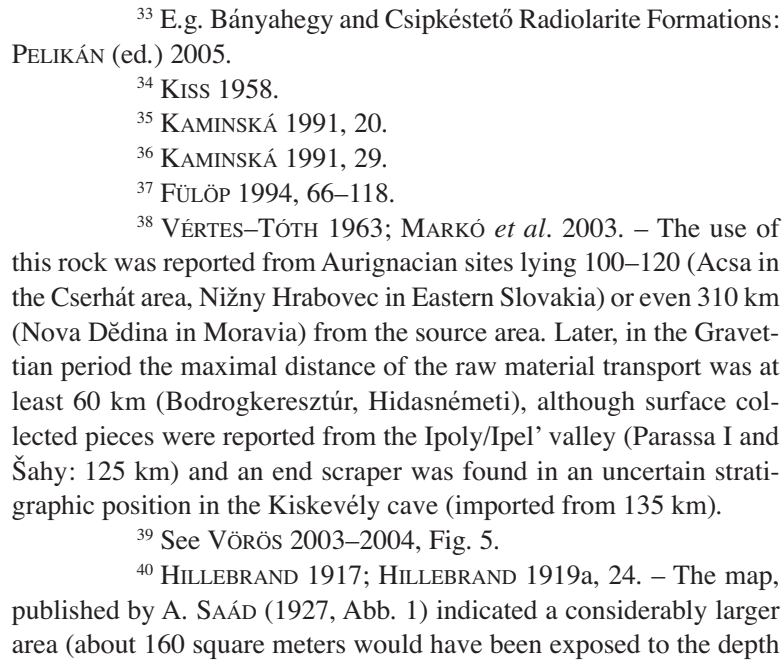

${ }^{33}$ E.g. Bányahegy and Csipkéstető Radiolarite Formations: Pelikán (ed.) 2005.

${ }^{34}$ KISS 1958.

${ }^{35}$ KAMINSKÁ 1991, 20.

${ }^{36}$ KAMINSKÁ 1991, 29.

${ }^{37}$ FÜLÖP 1994, 66-118

${ }^{38}$ VÉRTES-TÓTH 1963; MARKó et al. 2003. - The use of this rock was reported from Aurignacian sites lying 100-120 (Acsa in the Cserhát area, Nižny Hrabovec in Eastern Slovakia) or even $310 \mathrm{~km}$ (Nova Dĕdina in Moravia) from the source area. Later, in the Gravettian period the maximal distance of the raw material transport was at least $60 \mathrm{~km}$ (Bodrogkeresztúr, Hidasnémeti), although surface collected pieces were reported from the Ipoly/Ipel' valley (Parassa I and Šahy: $125 \mathrm{~km}$ ) and an end scraper was found in an uncertain stratigraphic position in the Kiskevély cave (imported from $135 \mathrm{~km}$ ).

${ }^{39}$ See VöRÖs 2003-2004, Fig. 5.

${ }^{40}$ Hillebrand 1917; Hillebrand 1919a, 24. - The map, published by A. SAÁD (1927, Abb. 1) indicated a considerably larger area (about 160 square meters would have been exposed to the depth

of 1-2 meters), which seems to be improbable, as a total of 36 days were spent in the cave by field works especially in 1913-17.

${ }^{41}$ Hillebrand 1914, 118; 1919, 10-13.

${ }^{42}$ Although according to the 1929 map by O. Kadic (published only in 1944 by KADIĆ and MоTTL) two thirds of the middle section of the cave was exposed to a depth of $1 \mathrm{~m}, \mathrm{~L}$. Vértes placed the bottom of the earlier trenches approximately to $2 \mathrm{~m}$ in the case of trench IV in his field notes. However, the published section does not show a single large trench with an even bottom but a deeper pit with infilling, starting from the flat surface of the earlier excavations VÉRTES 1955, Taf. LI, Abb. 3.

${ }^{43}$ The majority of the pieces found in 1912-1914 generally cannot be separated according to the excavation campaigns. Moreover, some of them were later published in the field report of the 1916 excavations (HILlEBRAND 1917, 106, Fig. 8.) like the pieces of inv. nr. $\mathrm{Pb} / 512$ or $\mathrm{Pb} / 834-835$, which were collected in 1912-14 according to the inventory book. The pieces inventorised in the Miskolc Museum (Inv. nr: 53.10.1-15) as artefacts from the 1918 season were found in fact in 1913 . 

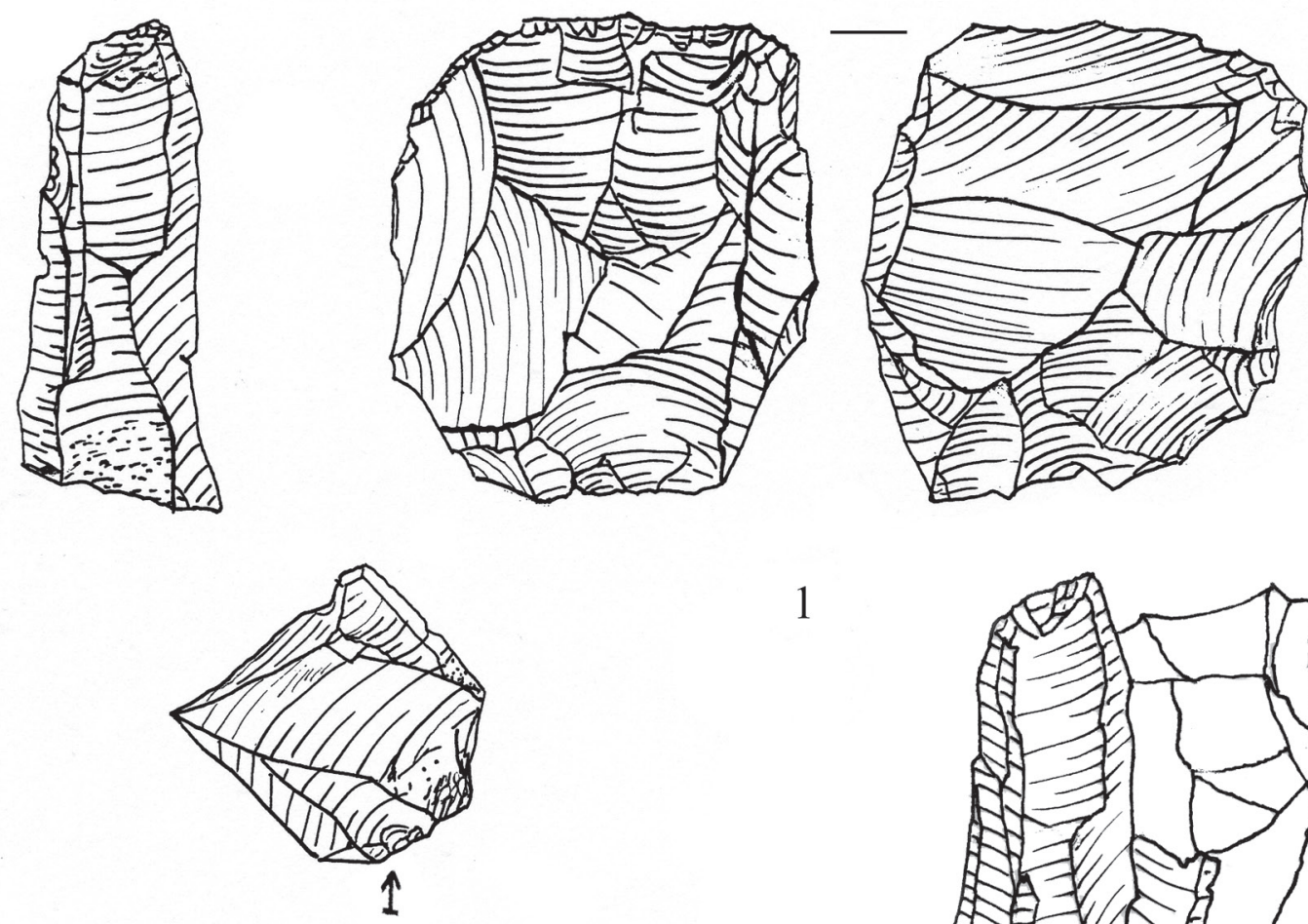

1
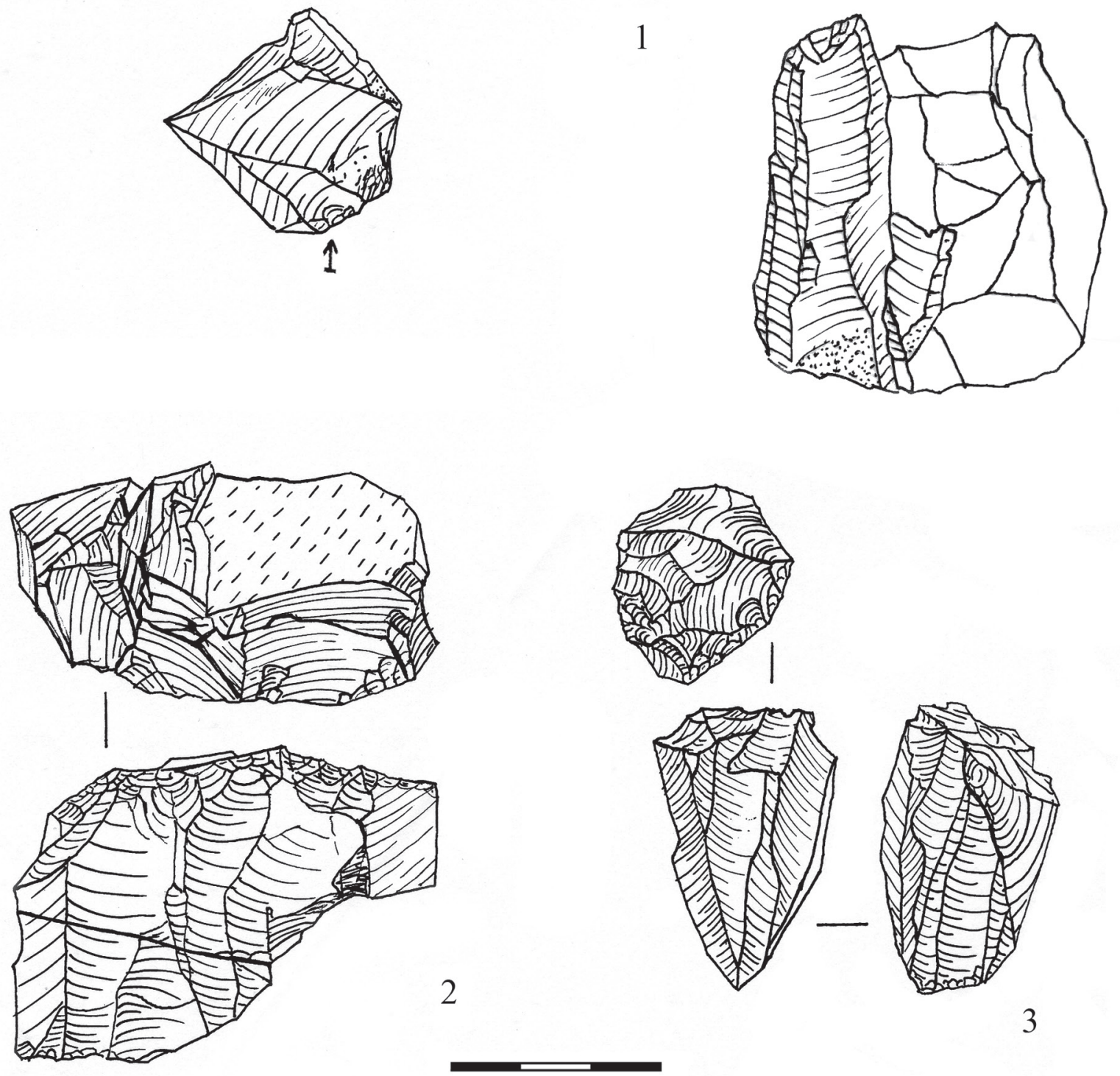

Fig. 2. Cores and refitted blanks (refit group 4 and 15) from the excavations by Hillebrand and Mottl (drawing by K. Nagy) 
Among the retouched tools (Table 5), end scrapers (including a circular piece: Fig. 6.6) dominate over bruins, which are represented by single pieces made on a concave truncation (Fig. 3.4) or on a broken surface. However, more than half of the formal tools are uni- and bilaterally retouched or even pointed blades (Fig. 4.1,8; 5.1-2) and six end-scrapers (Fig. 3.1-2) and two burins (Fig. 3.4) were also worked on their lateral edges. Importantly, three blunted bladelets (including a microgravette) and an alternately worked piece of radiolarite (Fig. 6.2), interpreted as a preform of a bifacial tool are also present in the assemblage.

During the short season of 1925, the culture-bearing layer was excavated in the middle section next to the cave wall and below a $1 \mathrm{~m}$ thick cemented limestone breccia. The same 'hearth' was identified in the test pit in the rear part but unfortunately, the pieces from the two trenches were mixed. In the collection there is a primary and a secondary crested blade and the group of the formal tools (Table 5) is once again dominated by retouched blades. The 'end scraper' with a narrow working edge may also be interpreted as the distal fragment of a unilaterally retouched blade. In this case, the only tool of a non-flint raw material is a side scraper. There are two blade fragments in the collection, which obviously belong together, although do not fit directly ${ }^{44}$ : the not patinated broken surface is clearly postgenetic in origin and can possibly be attributed to the effects of the excavations.

The first data about multiple Palaeolithic occupations in the Istálóskő cave were reported in 1927, when A. Saád and G. Megay (Museum of Miskolc) documented two 'Aurignacian' hearths separated by a sterile, $20 \mathrm{~cm}$ in thick clay layer in the rear part of the cave. Gravettian type artefacts and atypical blades were published from the upper hearth layer two bone tools from the lower one ${ }^{45}$ and a 'Prehistoric' hearth with burned human bones was excavated at the entrance of the cave. ${ }^{46}$ Twenty-two lithics have been deposited in the collection of the Herman Ottó Museum, Miskolc from this excavation (three of the four pieces of vein quartzite are probably natural in origin and not included in Table 3), possibly all from the 'upper hearth layer'. Beside the above-mentioned microgravette, there is a bilaterally retouched blade, a fragment of a side scraper of Mád-type obsidian and three blades with traces of use are worth mentioning (Table 6).

In 1929, O. Kadić removed the uppermost part of the sediment in the first sector and deepened the bottom of the trench opened by Hillebrand and Megay at the entrance of the cave until the bedrock, and finally he dug down to $3 \mathrm{~m}$ in the back part of the middle section. Despite these extensive works, we do not know either paleontological remains ${ }^{47}$ or artefacts $^{48}$ from these excavations.

M. Mottl opened $2 \mathrm{~m}$ deep trenches at the southern wall and in the middle section of the cave nine years later, and she identified Hillebrand's 'great hearth' which was, however, sterile from an archaeological point of view. In the rear section she carried on the excavations of the trench opened by Hillebrand and Saád to a depth of 4 meters and observed both hearth layers. Mottl stated in the field report that, concerning the planigraphical and stratigraphic position of the artefacts, the stone tools were found in the rear section in the yellowish brown layer (layer IV by Vörös) and only two pieces were recovered from the lateral and the middle sections of the cave. ${ }^{49}$ In her monograph of the Bükk region and the Aurignacian industry, ${ }^{50}$ she, however, wrote that the artefacts had come from the hearthlevels, and reported only a few pieces from the yellowish brown layer.

From this season, 17 lithics are stored in the collection of the National Museum. One of them is a conical blade core from Slovakian obsidian with a prepared striking platform and a distal part (Fig. 2.3). A pre-core with a prepared ridge made from andesite(?) and a crested blade from lydite are also present in the collection. Among the formal tools (Table 6), uni- and bilaterally retouched blades dominate in this case too, and the only end-scraper is also made on a bilaterally retouched blank. Some pieces like an end scraper with a high working edge from silicified wood and the relatively 'fresh' raw material of certain pieces, or the proximal blade fragments (traces of punching technique) of refit group 6 suggest, that at least a few lithics were mixed in from younger deposits.

\footnotetext{
${ }^{44}$ Hillebrand 1926, Abb. 7.

${ }^{45}$ SAÁD 1927; 1929, 238-239.

${ }^{46}$ SAÁD 1929, 240.

47 VÖRÖS 2003-2004, 49

${ }^{48}$ However, both Aurignacian and Magdalenian lithics were reported from the entrance section: KADIĆ-MoTTL 1944, 40-41.

${ }^{49}$ MotTL 1945, 1538, 1546.
}

\footnotetext{
${ }^{50}$ Kadić-MotTl 1944, 54; MotTL 1942, 84. - On page 92 of this latter work, the archaeological material was again originated from the yellowish brown layer (МоттL 1942, 92). A more general problem of the cross sections published by Mottl is that such parts of the cave were also depicted that were eventually not excavated at all, at least according to the map and the description of the same articles (e.g. the 2 meter thick section at 38 meters or the 2 meter long section of the profile at 26 meters: MotтL 1945, 1536).
} 


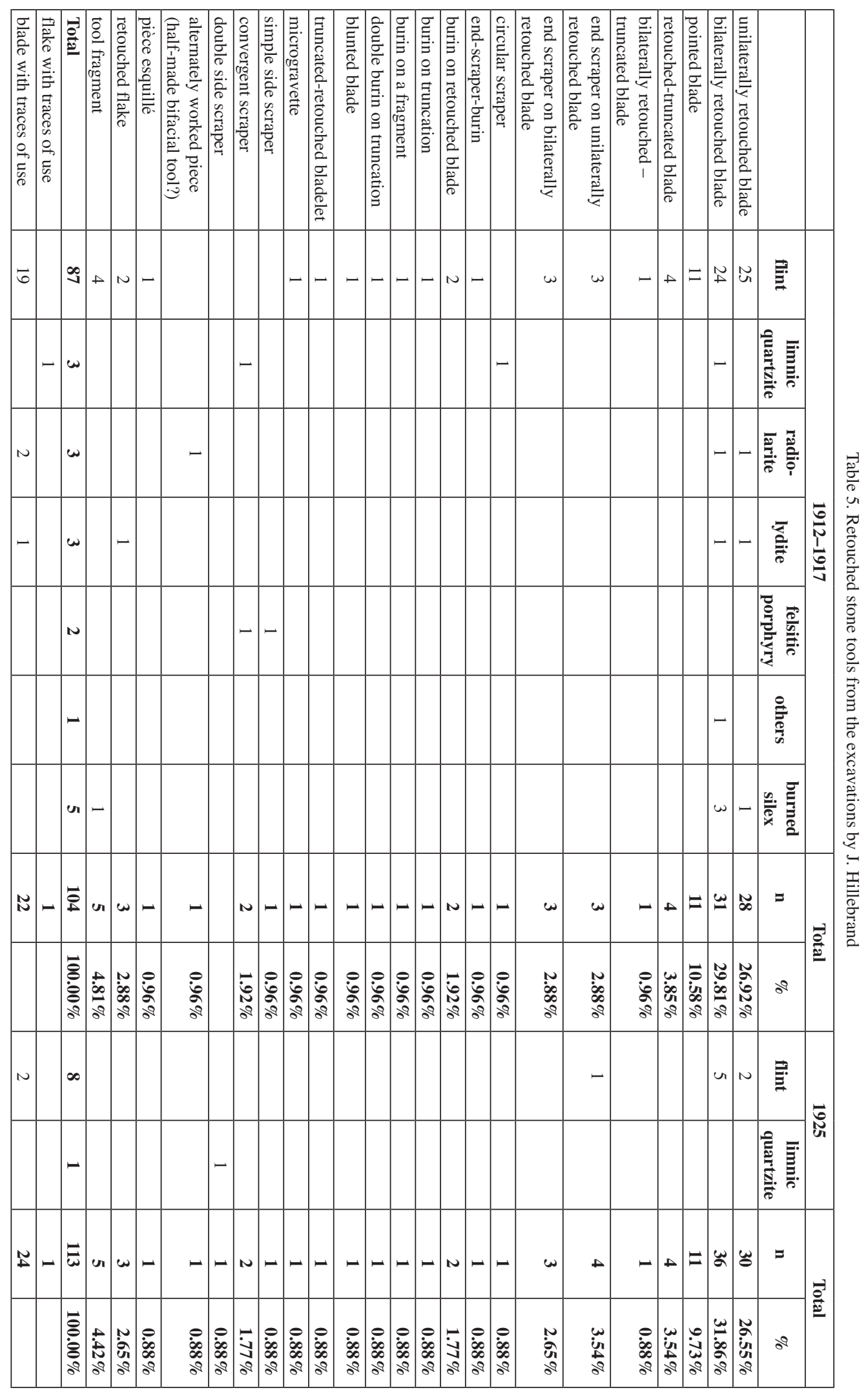



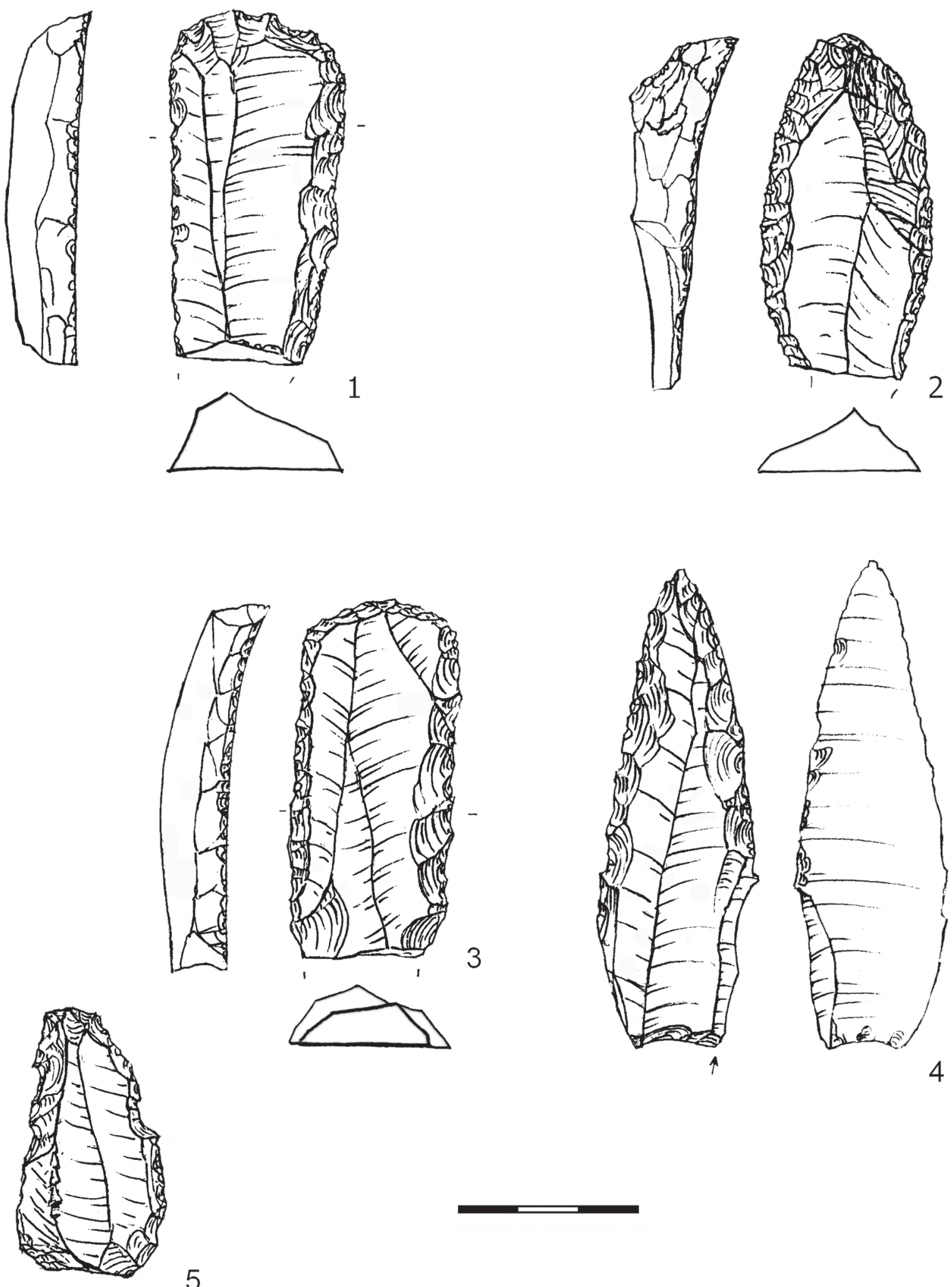

Fig. 3. End-scrapers and a burin made on laterally retouched blades (drawing by K. Nagy) 
Table 6. Retouched tools from the excavations by A. Saád and M. Mottl

\begin{tabular}{|c|c|c|c|c|c|c|c|}
\hline & \multicolumn{3}{|c|}{ Saád excavations 1927} & \multicolumn{3}{|c|}{ Mottl excavations 1938} & \multirow[b]{2}{*}{ Total } \\
\hline & flint & lydite & obsidian & flint & lydite & other & \\
\hline unilaterally retouched blade & 1 & & & 1 & 1 & & 3 \\
\hline bilaterally retouched blade & 1 & & & 2 & & & 3 \\
\hline end scraper on bilaterally retouched blade & & & & 1 & & & 1 \\
\hline end-scraper with high working front & & & & & & 1 & 1 \\
\hline microgravette & 1 & & & & & & 1 \\
\hline transversal scraper & & & 1 & & & & 1 \\
\hline pièce esquillé & & & & 1 & & & 1 \\
\hline worked flake, (atypical) & & & & 1 & & & 1 \\
\hline tool fragment & & & & 1 & & & 1 \\
\hline total & 3 & & 1 & 7 & 1 & 1 & 13 \\
\hline blade with traces of use & 2 & 1 & & 2 & & & 5 \\
\hline
\end{tabular}

Table 7. Retouched tools from the 1947 excavations by L. Vértes

\begin{tabular}{|c|c|c|c|c|c|c|c|c|c|}
\hline & \multicolumn{4}{|c|}{ at the large fireplace } & \multicolumn{4}{|c|}{ rear part of the cave } & \multirow[b]{2}{*}{ Total } \\
\hline & flint & $\begin{array}{c}\text { limnic } \\
\text { quartzite }\end{array}$ & lydite & $\begin{array}{c}\text { burned } \\
\text { silex }\end{array}$ & Total & flint & $\begin{array}{c}\text { limnic } \\
\text { quartzite }\end{array}$ & $\begin{array}{c}\text { burned } \\
\text { silex }\end{array}$ & \\
\hline unilaterally retouched blade & 4 & & & 1 & 5 & & & & \\
\hline bilaterally retouched blade & 1 & & & & 1 & & & & \\
\hline blunted bladelet & 1 & & & & 1 & & & & \\
\hline biliterally blunted bladelet & 1 & & & & 1 & & & & \\
\hline microgravette & & & & & & 2 & & & 2 \\
\hline transversal scraper & & & & & & & 1 & & 1 \\
\hline tool fragment & & & & & & & & 1 & 1 \\
\hline total & 7 & & & 1 & 8 & 2 & 1 & 1 & 4 \\
\hline flake with traces of use & & 1 & & & 1 & & & & \\
\hline blade with traces of use & 1 & & 1 & & 2 & & & & \\
\hline
\end{tabular}

The next excavations were carried out by L. Vértes in 1947, when a large hearth lined surrounded by stone slabs was elevated and later exhibited in situ. ${ }^{51}$ Among the lithics found here (Table 7), five retouched and two blunted bladelets (Fig. 6.4,8,9) are worth mentioning. Furthermore, only nine pieces (among others two blunted bladelets, a double-sided retouched blade, a borer and a double end-scraper) are known only from the literature, which were not recovered from the surface of the hearth. ${ }^{52}$ In the trench of the rear section, intact cave bear skulls (interpreted as a 'skull deposition' or a 'cult place' at that time ${ }^{53}$ ) were found together with a few retouched tools, including Gravettian types (Table 7).

Next year, a trial trench was opened at the entrance of the cave in order to show the layer sequence to the planned INQUA Congress. The earlier found level of the Aurignacian artefacts was designated as 'layer $f$ ' ('warm brown Aurignacian clay', layer III and I: Table 2), however, the two stone tools (one of them is missing from the collection, the other one is a non-diagnostic medial blade fragment from radiolarite) and the bone fragments were found in layer $c$ (i.e. layer V) and were classified in the 'Magdalenian' period.

\footnotetext{
${ }^{51}$ VÉRTES 1951.

52 VÉRTES 1951, 26-27.
} 

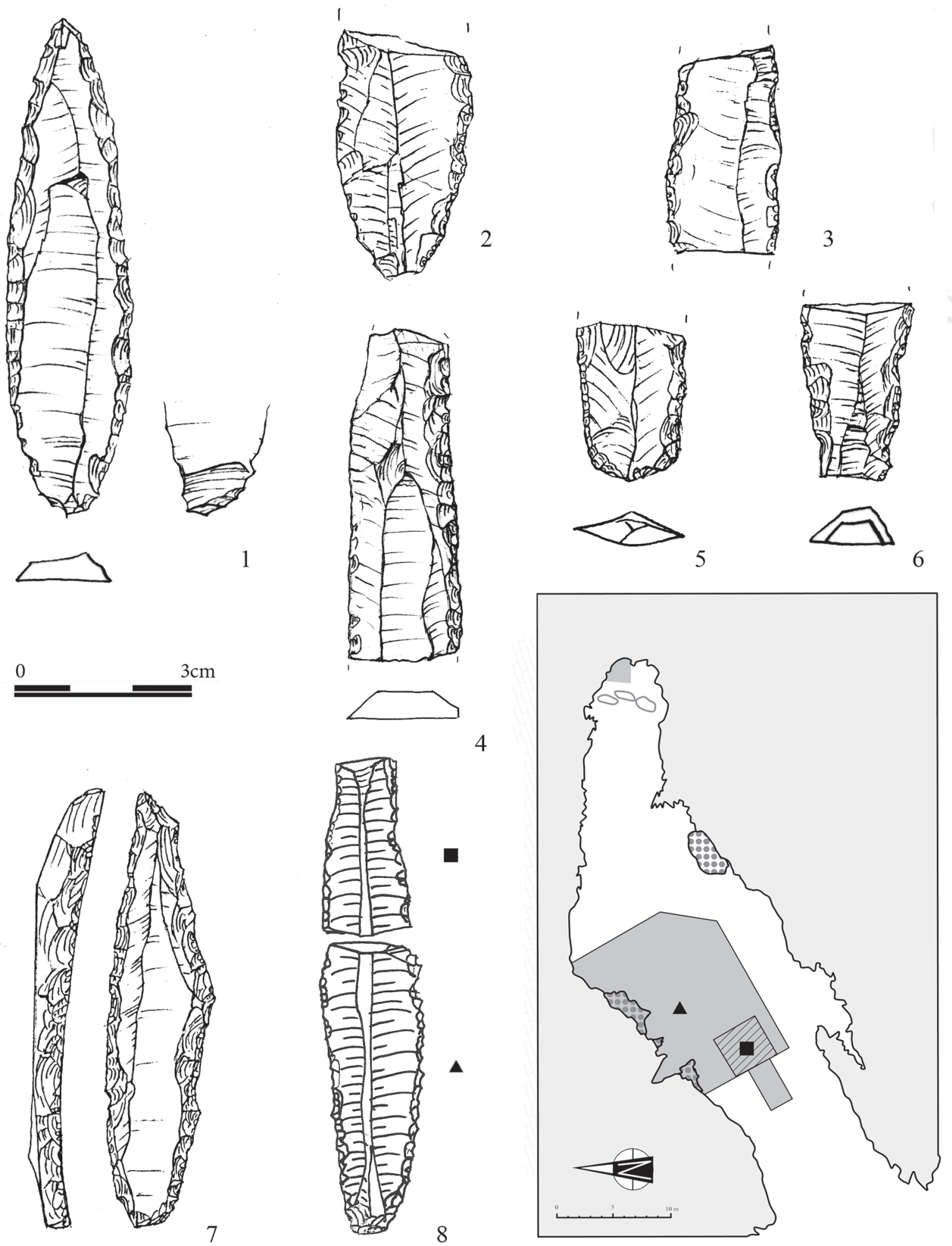

Fig. 4. Uni- and bilaterally retouched blade fragments and blade points excavated by J. Hillebrand and L. Vértes (drawing by K. Nagy) 

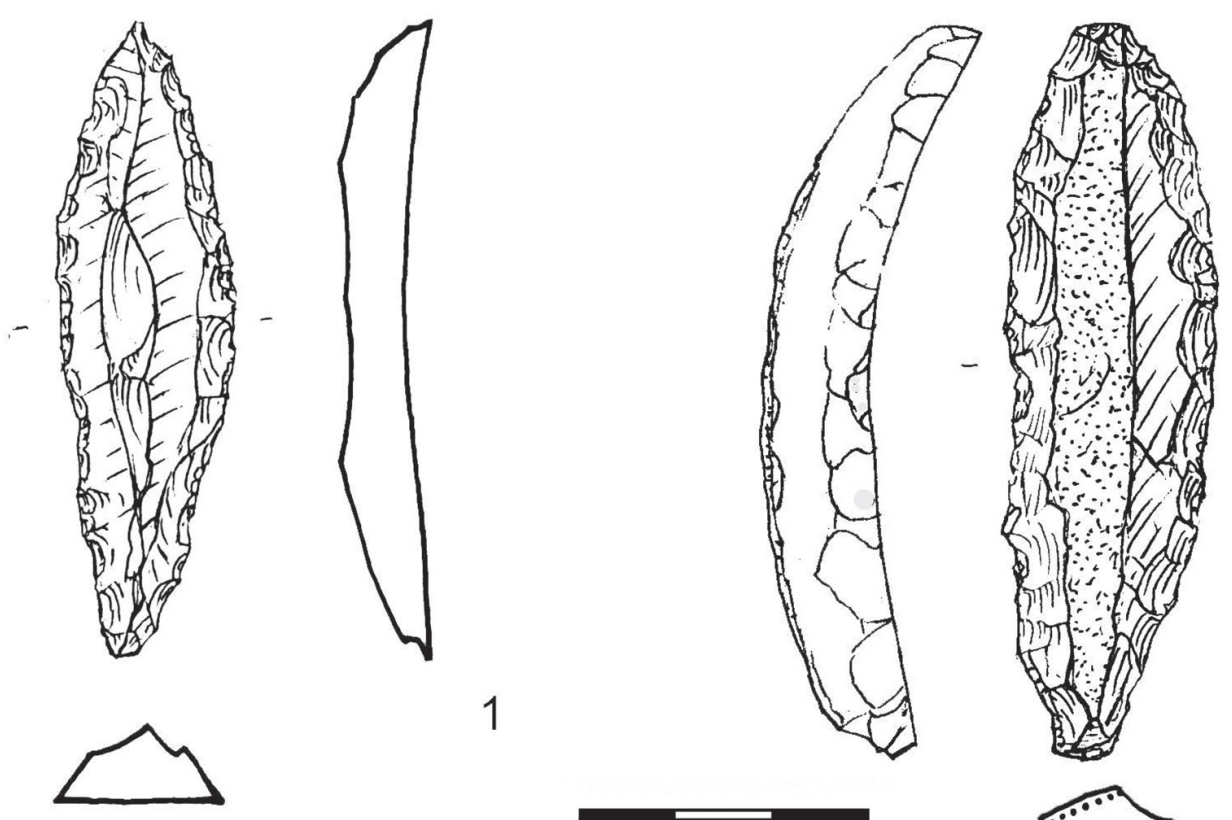

2

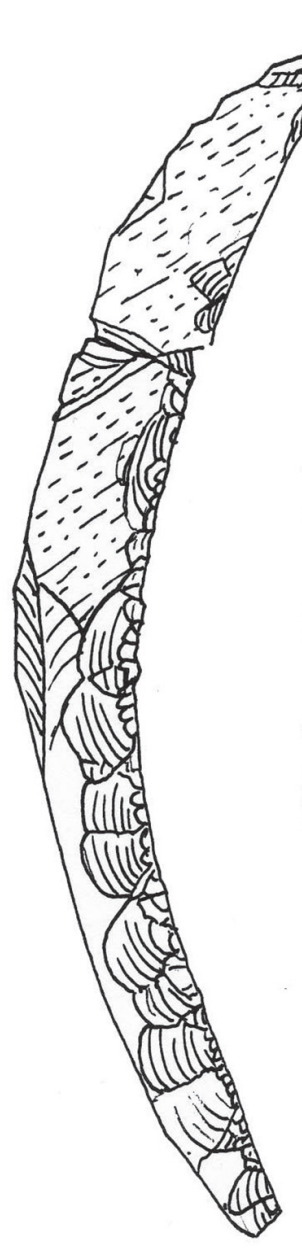

1
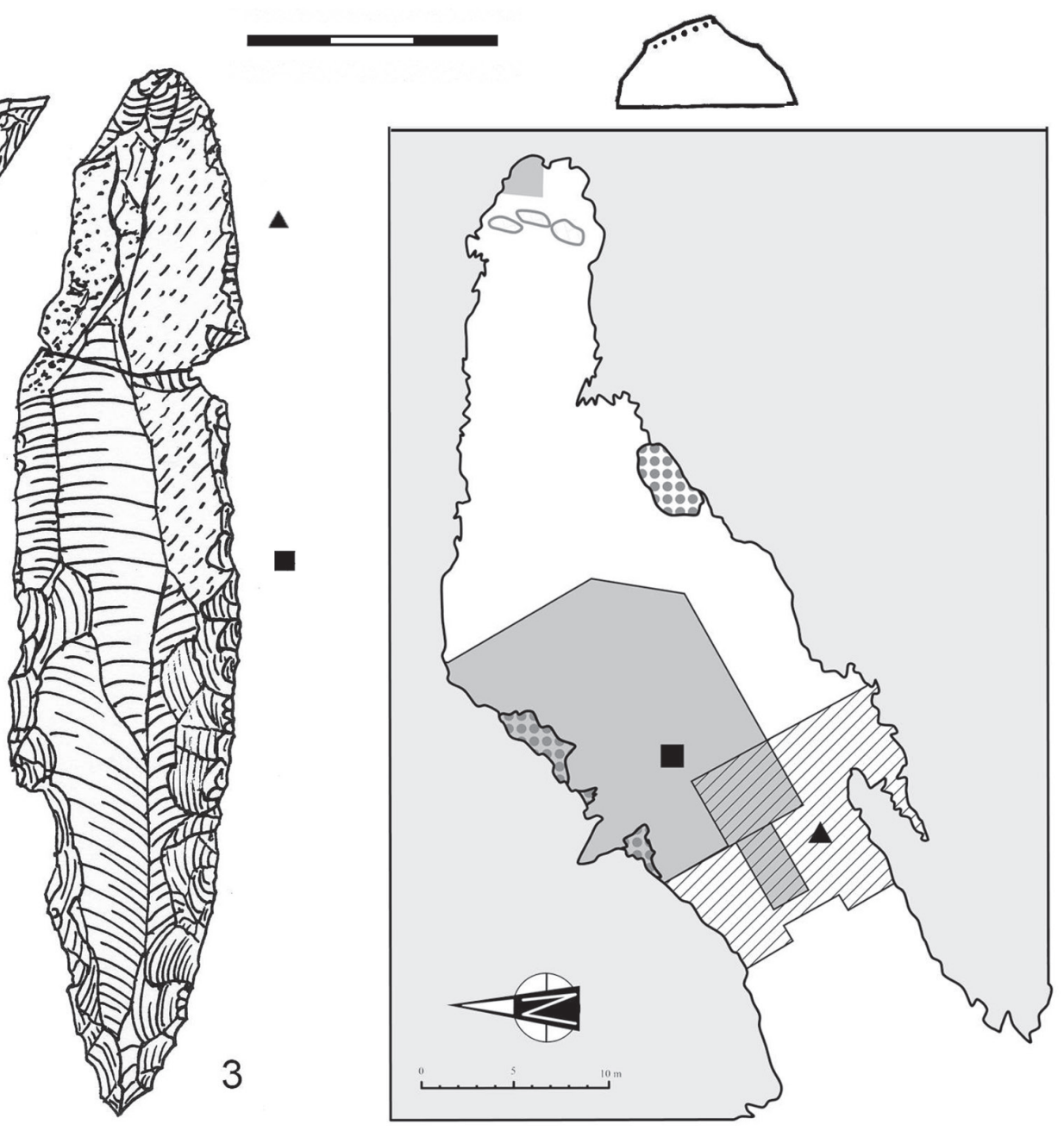

Fig. 5. Retouched blade points from flint from the upper layer (drawing by K. Nagy) 

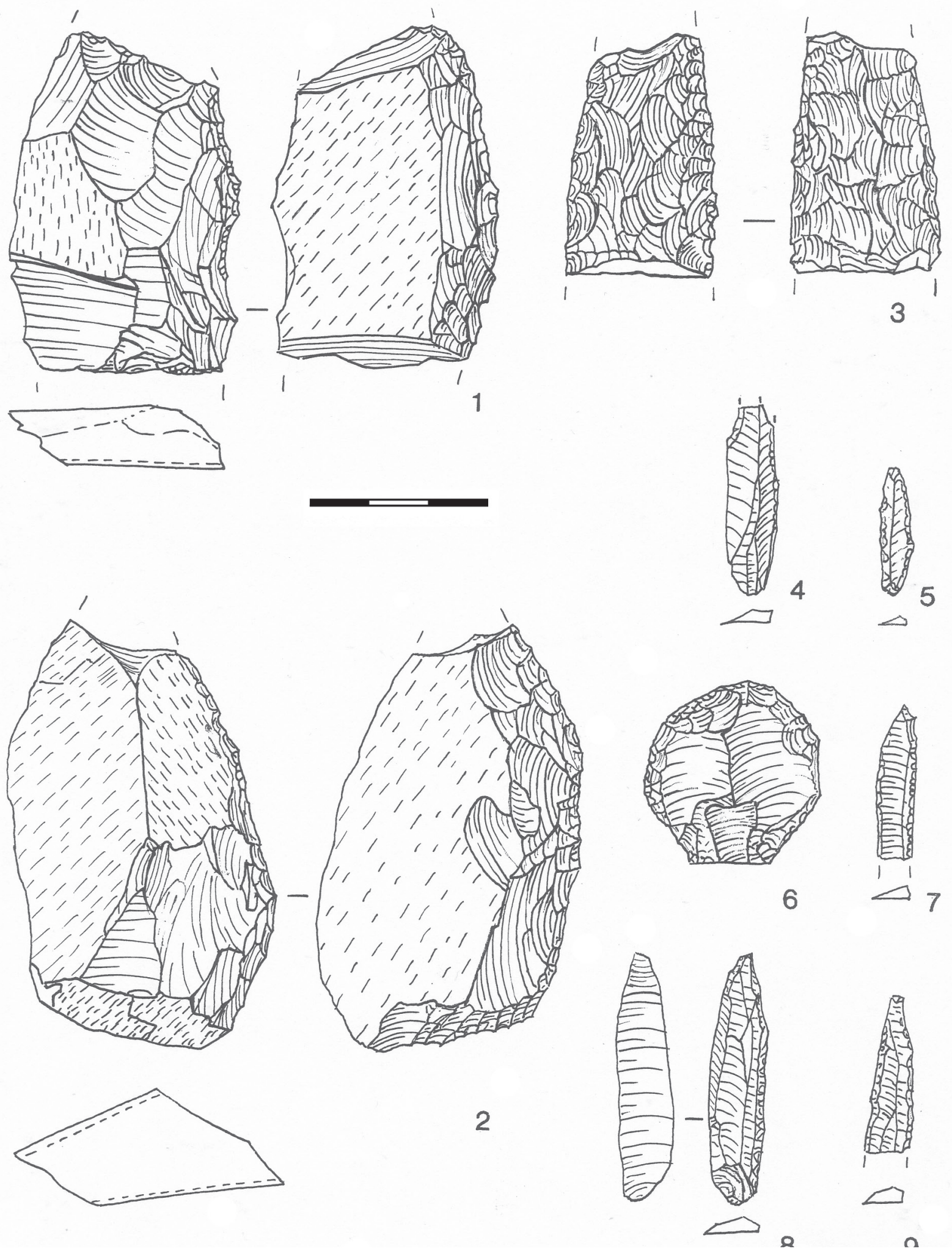

Fig. 6. Bifacial tools, preforms and blunted elements from the upper layer (drawing by K. Nagy) 
During the 1950-51 excavations, Vértes exposed 160 square meters to a depth of $2.5 \mathrm{~m}$. The next years, a few test trenches were opened in the cave with the aim of sampling for sedimentological and radiocarbon studies, which completed our knowledge of the chronological position of the assemblages and yielded a few important artefacts. In the following we discuss the results of the 1950-1965 seasons together.

Two main culture-bearing layers (identified as Aurignacian I and II, with split based points and Mladeč/ Olschewa-type osseous artefacts) linked to layer I and III and a few 'Magdalenian' artefacts (later sorted into phase II or III of the Aurignacian industry ${ }^{54}$ ) were identified. As the archaeological material was extensively published by Vértes, ${ }^{55}$ we will shortly discuss only those aspects of the assemblages that seem to be interesting even after six decades.

In certain cases, it was difficult or even impossible to separate both the sedimentological and the archaeostratigraphical units during the excavations. ${ }^{56}$ Unfortunately, some of the most peculiar and most important artefacts, like the bone flute ('Olschewian tool' in the field notes ${ }^{57}$ ) and the felsitic porphyry leaf point (Fig. 6.3), ${ }^{58}$ both found below a mushroom-like travertine formation at the northern wall of the cave in trench IV, were uncovered in an extremely complex stratigraphic position right next to the wall of the cave.

In 1950-51, a total of 97 lithics ${ }^{59}$ were uncovered in the generally $40 \mathrm{~cm}$ thick 'upper layer', in the reddish brown layer III. This stratigraphical unit was absent in trench II as the earlier excavations removed the imbedding sediments, but relatively numerous lithics were documented near the northern wall of the cave (trench III, IV and X). The high number of artefacts from trench VIII is obviously the result of the fine excavation methods employed here.

An exhausted bipolar core fragment of limnic quartzite pebble is interesting to note among the technological pieces. The other core with unidirectional scars and prepared lateral and distal parts of refit group 17 (Fig. 7.4) was made from poor quality ('Korlát-type') limnic quartzite. Besides, there are only two crested blades from the same raw material in the assemblage.

Both artefacts and formal tools from flint are relatively poorly represented (e.g. by retouched blades: Fig. $4.2-3,5-7)$ in the collection, at least as compared to the material excavated before WW II. At the same time, the number of bilaterally retouched blades decreased, burins are absent (Table 8), while 'archaic' types (typical side scrapers and two Mousterian points) made from limnic quartzite and radiolarite make up one third of the formal tools (Fig. 8). Importantly, beside the well-known leaf point fragment (Fig. 6.3) from felsitic porphyry, a half prepared bifacial tool of the same raw material (Fig. 6.1) is also present in the collection.

The artefacts from the upper part of the yellowish brown layer V were placed into the 'Magdalenian' period from the beginning of the excavations, even if the micromammal material showed a fauna of a steppe-like character with the lack of lemming remains ${ }^{60}$ and the poor archaeological material did not basically differ from the main industry of the cave. ${ }^{61}$ Our work supports this observation as neither the raw material composition (flint, radiolarite, limnic quartzite and felsitic porphyry: Table 3) nor the lithic tool types (two side scrapers from flint and limnic quartzite, a retouched flake from radiolarite and a few pieces with traces of use) are unknown in the main industry of the cave.

The 'lower hearth layer' or 'Aurignacian I layer' was first identified in 1950 in the light brown layer I and it yielded a total number of 45 lithics; seven of them are natural in origin (pebbles of limestone and vein quartzite) and not included in Table 3. The detailed data on the provenance of 26 lithics are known at least on the level of the trenches and the depth: half of them were found close to the entrance of the cave (trench I-III, seven of them in trench III); four lithics including a core (Fig. 9.2) and blades together with osseous tools ${ }^{62}$ in a $30 \mathrm{~cm}$ cutting in trench VI at the southern wall of the cave.

54 VÉRTES 1955, 127-128.

55 VÉRTES 1955, 114-130.

${ }^{56}$ E.g. VÉRTES 1955, 114. - For example the artefacts from the richest level of the cave (from the depth of -1.5-1.8 $\mathrm{m}$ in trench III) were placed partly into the upper (excavated 1 June 1950), partly to the lower culture-bearing layer (e.g. the burin-like core of Fig. 9.5 on 3 June). Moreover, the pieces from level 1 (0-0.8 $\mathrm{m}$ in depth) in trench IV were sorted to the 'upper layer', with the exception of a single piece, found at the depth of $0.4 \mathrm{~m}$, identified as 'Magdalenian'.
${ }^{57}$ Dobosi 2002, 84-85.

${ }^{58}$ VÉRTES 1955, 126. - c.f. note 15.

${ }^{59}$ VÉRTES 1955, 121, 127.

${ }^{60}$ MotTl 1942, 92.

${ }^{61}$ E.g. Dobosi 2002, 89.

${ }^{62}$ Among others, a piece intrpreted as 'shouldered' or split based point: VÉRTES 1955, 118, Taf XXVI,7; DoBOSI 2002, 99. 


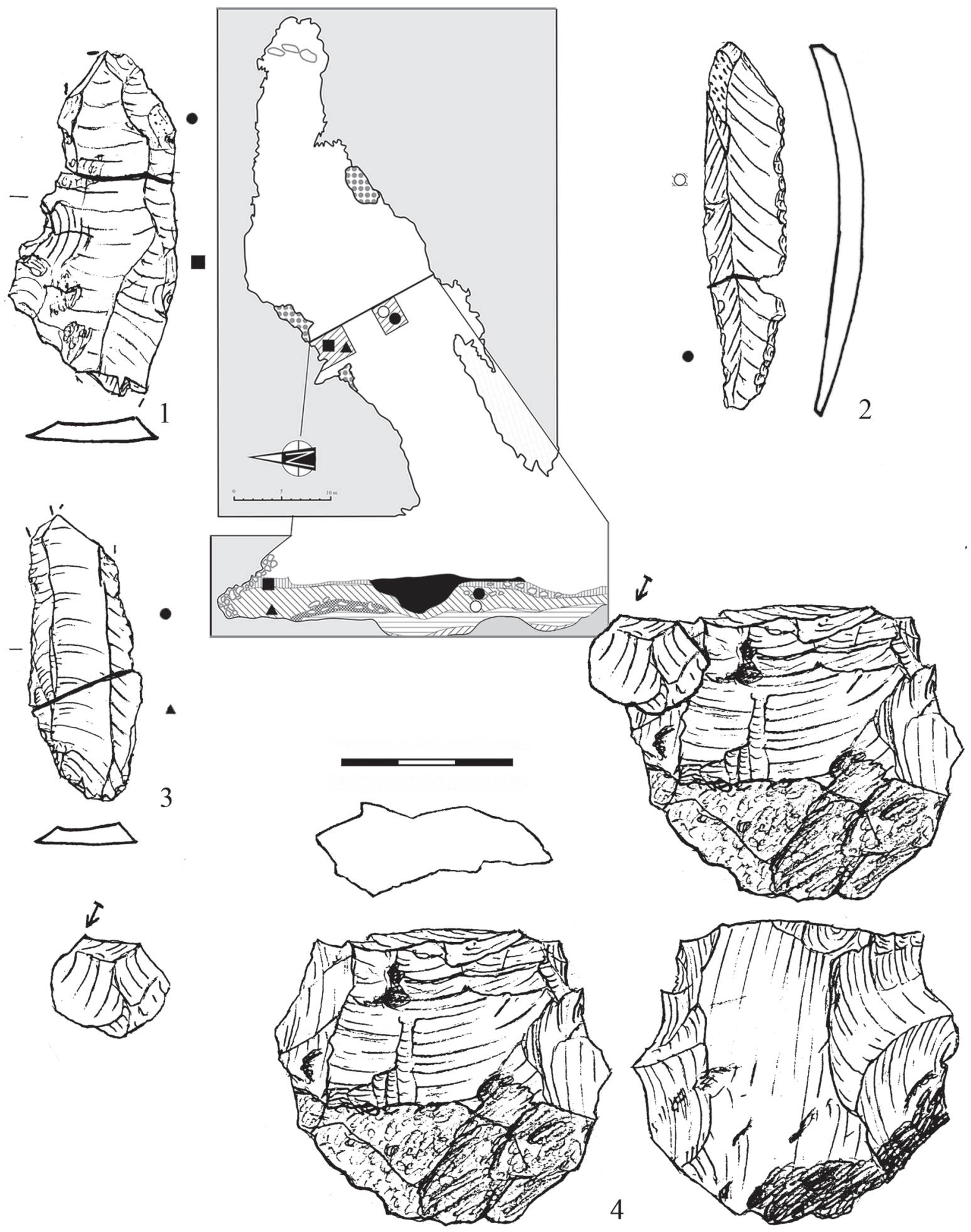

Fig. 7. Refit groups from the upper culture-bearing layer, excavated by L. Vértes (drawing by K. Nagy) 
Table 8. Retouched tools of the upper layer by L. Vértes

\begin{tabular}{|c|c|c|c|c|c|c|c|c|c|}
\hline & flint & $\begin{array}{c}\text { limnic } \\
\text { quartzite }\end{array}$ & $\begin{array}{l}\text { radio- } \\
\text { larite }\end{array}$ & lydite & $\begin{array}{c}\text { felsitic } \\
\text { porphyry }\end{array}$ & obsidian & quartzite & others & Total \\
\hline unilaterally retouched blade & 4 & 2 & 2 & 1 & & & & 1 & 10 \\
\hline bilaterally retouched blade & 2 & & & & & & & & 2 \\
\hline pointed blade & 2 & & & & & & & & 2 \\
\hline $\begin{array}{l}\text { end scraper on unilaterally } \\
\text { retouched blade }\end{array}$ & & 1 & 1 & & & & & & 2 \\
\hline $\begin{array}{l}\text { end scraper on bilaterally } \\
\text { retouched blade }\end{array}$ & 2 & & & & & & & & 2 \\
\hline blunted-retouched bladelet & 1 & & & & & & & & 1 \\
\hline simple side scraper & 1 & & 2 & & & & & & 3 \\
\hline transversal scraper & & 1 & & 1 & & & & & 2 \\
\hline convergent scraper & & 1 & & 1 & & & & & 2 \\
\hline double side scraper & & 1 & & & & & & & 1 \\
\hline $\begin{array}{l}\text { side scraper worked on three } \\
\text { edges }\end{array}$ & & 1 & & & & & & & 1 \\
\hline Mousterian point & & 1 & 1 & & & & & & 2 \\
\hline leaf shaped point & & & & & 1 & & & & 1 \\
\hline $\begin{array}{l}\text { alternately worked piece } \\
\text { (half-made bifacial tool?) }\end{array}$ & & & & & 1 & & & & 1 \\
\hline retouched flake & & & & & & & 1 & & 1 \\
\hline tool fragment & & 3 & & 1 & & & & & 4 \\
\hline total & 12 & 11 & 6 & 4 & 2 & & 1 & 1 & 37 \\
\hline blade with traces of use & 2 & 4 & 1 & 1 & 1 & 1 & & 1 & 11 \\
\hline
\end{tabular}

Flint, lydite and the five radiolarite variants are mainly represented by individual blade fragments. Among the other raw materials, there are relatively numerous artefacts from obsidian (of the Slovakian and a small fragment of Tolcsva type) and felsitic porphyry (two tools and a small chip).

There are only two cores in the assemblage. One of them from limnic quartzite with a flat flaking surface and centripetal scars (Fig. 9.2) was originally interpreted as an atypical high scraper, ${ }^{63}$ while the other piece from grey radiolarite bearing unidirectional scars was shaped similarly to the burins (Fig. 9.5). Besides, an atypical crested blade from Korlát-type limnic quartzite is also present in the collection.

The most common formal tools are retouched blades (Fig. 9.1) and heavily fragmented retouched blanks (Fig. 9.4,6-9), sometimes referred to as 'raclettes' (Table 9). The mostly irregular, sometimes inverse scars on the edges of these fragments are interpreted partly as traits of natural (taphonomic) processes, ${ }^{64}$ partly as a human answer to blank fragmentation. We present the refit group 8 as a typical example, which contains three fragments of a single radiolarite blade (Fig. 10.1): the medial and proximal parts, broken during secondary working, were originally interpreted as retouched blade fragments, the distal fragment as a raclette or a borer. ${ }^{65}$

The rest of the tool types are represented by single specimens. The end-scraper, made on a short blade-like flake (Fig. 9.3) is a quite common although not typically Aurignacian form and possibly one of the retouched blade fragments (Fig. 9.4) might originally also be a similar tool type, which got later heavily fragmented. Finally, the borers and the convergent scrapers are atypical pieces and the only burin was shaped by a few spalls on the mentioned core-like piece (Fig. 9.5).

${ }^{63}$ VÉRTES 1955, 120.

${ }^{64}$ Partly caused by natural impacts (frost): HAHN 1977, 122. - We have to point out, that the ventral scar on the 'pièce esquillé', mentioned by him is slightly patinated and clearly secondary as compared to the other part of the tool: Fig. 9.9, see also: HAHN 1977, Taf. 145:5.

${ }^{65}$ Hahn 1977, 122, Taf. 145:3. 

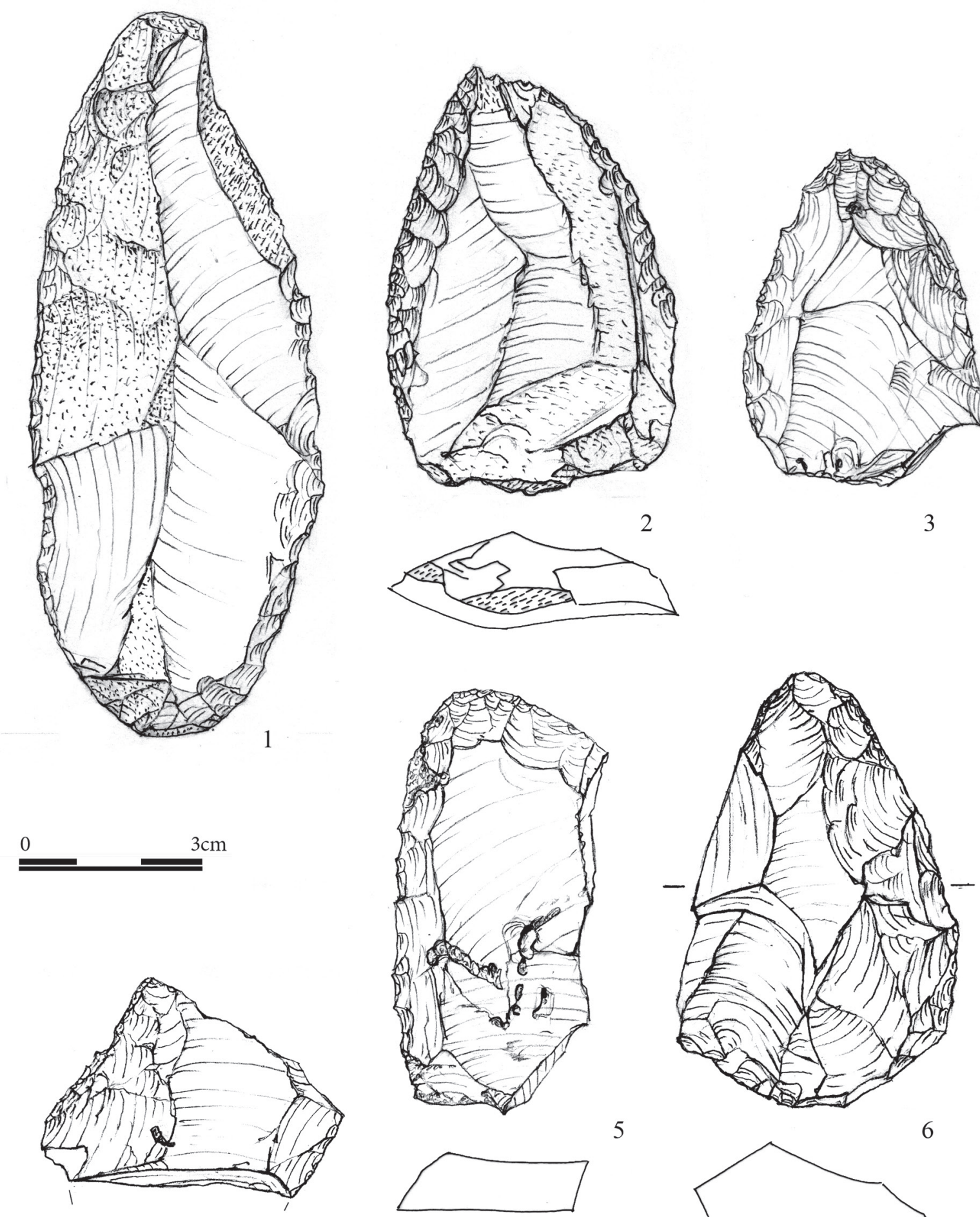

5

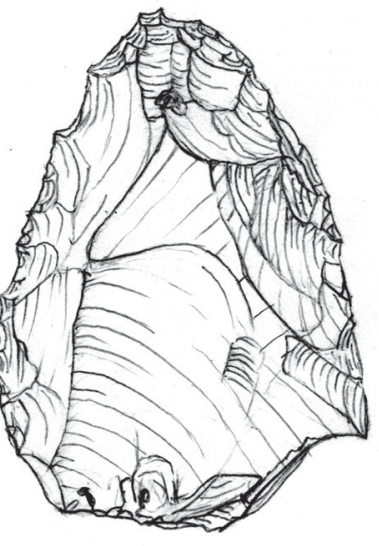

2
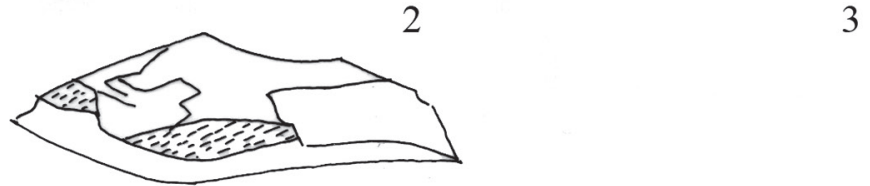

4

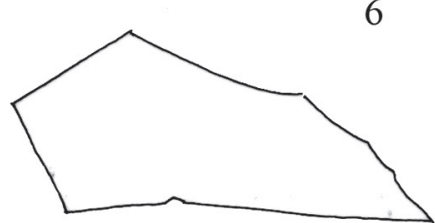

Fig. 8. Middle Palaeolithic type tools from radiolarite $(1,2,6)$ and limnic quartzite $(3,4,5)$ from the upper layer, excavated by Vértes (drawing by K. Nagy) 

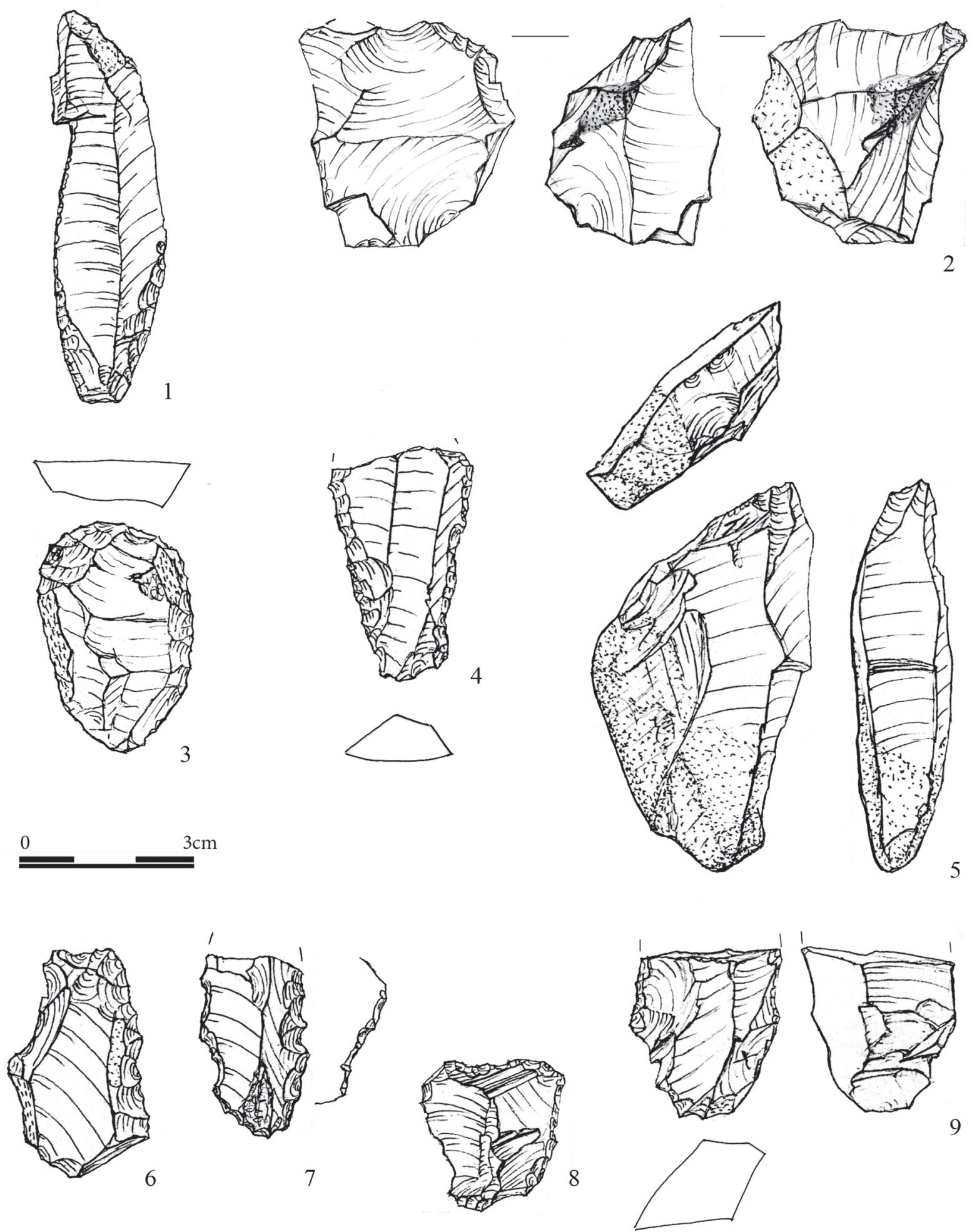

Fig. 9. Fragments of retouched blanks and cores from the lower culture-bearing layer by Vértes (drawing by K. Nagy) 

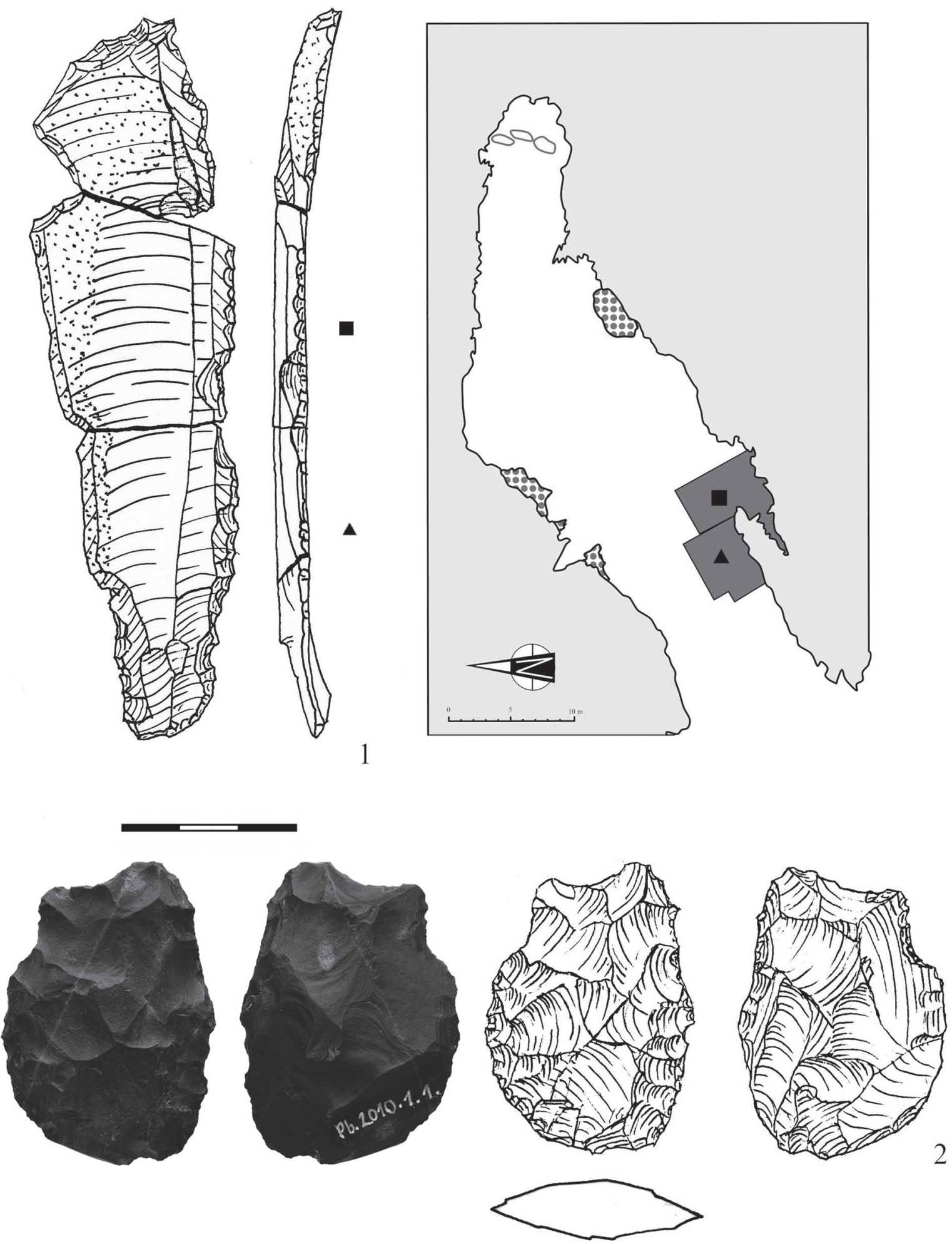

Fig. 10. Lower layer of the Istállóskő cave: refit group 9 and the leaf shaped scraper - $c f$. VÉRTES 1961, Abb. 1 (drawing by K. Nagy, photo: A. Dabasi) 
The most important and most diagnostic piece of this layer is a leaf shaped scraper (Fig. 10.2). This piece was found during radiocarbon sampling in $1958^{66}$ close to reference trench VIII and was later mixed in a box of artefacts from the Jankovich cave. This plano-convex tool with naturally fragmented distal part, was probably made on a large flake, retouched on the dorsal side and thinned on the ventral one. The tool was made from the same variant of radiolarite as one of the retouched fragments (Fig. 9.6).

\section{‘ABSOLUTE’ DATES OF THE ISTÁLLÓSKŐ CAVE}

Istállóskő cave is one of the few Palaeolithic sites in Hungary where a large number of radiocarbon dates are available (Table 10); their interpretation is, however, not without problems. The first dated sample from Istállóskö cave, and also from Hungary was collected from the grey debris layer between the two main culturebearing layers and gave an age of $31.5 \mathrm{kys}$ B.P. This part of the cave infilling was regarded as belonging to the lower culture layer and it was suspected that the small sample might have been contaminated ${ }^{67}$ and so the real age of the Aurignacian I industry was tentatively placed to the period before $36 \mathrm{kys}^{68}$ In 1965, new samples were collected from the base and the upper part of layer I, ${ }^{69}$ which yielded considerably older data: 44.3 kys and 39.8 kys B.P. ${ }^{70}$ During the 2000 excavations, several bone samples were collected from the levels below and over the reddish brown clay, identified as the hearth layers mentioned by Vértes, ${ }^{71}$ or interpreted as two cave soil horizons. ${ }^{72}$

Twelve antler tools were sampled from the Aurignacian I layer four years later. Regrettably, only one of them yielded an acceptable age and as lithic artefact were also found $0.4-0.8 \mathrm{~m}$ below this antler tool, the $35 \mathrm{kys}$ can only be a minimum age for the lower layer.

Three antler tools were sampled from the upper culture-bearing layer, however, all the measurements failed and so only absolute dated ecofacts are available from this industry. The 31 kys old conventional date measured on a charcoal sample was collected in 1958 from the lower horizon of the culture-bearing layer and it is in good accordance with the 31-28 kys old dates from the 'Aurignacian II hearth' of the excavations in 2000. The last series of radiocarbon measurements yielded an age of $31 \mathrm{kys}$ from the 'lower «Upper Aurignacian» hearth' and a 30 kys old one from the topmost charcoal lenses.

As a summary the upper culture-bearing layer can tentatively be placed to 31-28 kys B.P., the lower one to 53-33 kys B.P. This way the value of the first radiocarbon data well agrees with the stratigraphic position of the sample between the two culture-bearing layers and the dates older than 40 kys most probably do not belong to the archaeological artefacts.

\section{DISCUSSION - CULTURAL DETERMINATION OF THE 'LOWER LAYER'}

The 'lower culture-bearing layer', documented in the light brown layer I is exclusively known from the excavations by L. Vértes, however, earlier trenches might have reached the same level. ${ }^{73}$ In spite of the lack of the typical lithics, the assemblage was identified as Aurignacian I, ${ }^{74}$ early Aurignacian ${ }^{75}$ or Olschewian ${ }^{76}$ after the presence of split based antler points. At the beginning of the 1980s, the material was compared to the material found in layer 11 and 9 of the Bacho Kiro cave, Bulgaria, ${ }^{77}$ which was regarded as the oldest Upper Palaeolithic industry in Europe at that time. Recently, however, the 'Bachokirian' industry is classified as a late Middle Palaeolithic-like entity using

${ }^{66}$ VÉRTES 1961.

${ }^{67}$ VÉRTES-DE VRIES 1959.

68 VÉRTES 1965, 174.

${ }^{69}$ In the original field report the bones were linked to the lower, dark brown Aurignacian I clay and the overlying light brown layer, probably identical with the cave loess layers $f$ and $h$ : RINGER 2002, Fig. 2.

${ }^{70}$ The data are generally considered as being too old: GÁBORI-CSÁNK 1970, 9-10.

${ }^{71}$ ADAMs 2002, 54
${ }^{72}$ Layers $i$ and $j$ : RINGER 2002, Fig $2 \mathrm{~b}$.

${ }^{73}$ According to Mottl, the greyish brown clay with stone debris was sterile from an archaeological point of view possibly because of the small trenches and the scarce archaeological materials: MotTl 1942, 84; 1945, 1537 - see also: VÉRTES 1955, 113.

${ }^{74}$ E.g. VÉRTES 1955.

${ }^{75}$ BÁNESZ 1976, 64.

${ }^{76}$ VALOCH 1968, 359.

77 GINTER-KOZŁOWSKI 1982, 163, 170. - With a tool published as a split based point from layer 9 . 
Table 9. Retouched tools of the lower layer, excavated by L. Vértes

\begin{tabular}{|c|c|c|c|c|c|c|}
\hline & flint & radiolarite & $\begin{array}{c}\text { felsitic } \\
\text { porphyry }\end{array}$ & $\begin{array}{c}\text { limnic } \\
\text { quartzite }\end{array}$ & quartzite & Total \\
\hline end scraper on laterally retouched blade & & & & 1 & & 1 \\
\hline burin & & 1 & & & & 1 \\
\hline retouched fragmented blanks & & 4 & 1 & & & 5 \\
\hline borer / convergent scraper & & & & 1 & 1 & 2 \\
\hline blade worked on one edge & 1 & & 1 & 1 & & 3 \\
\hline blade worked on both edges & 2 & 1 & & & & 3 \\
\hline leaf shaped scraper & & 1 & & & & 1 \\
\hline fragment of a retouched tool & 1 & & & & & 1 \\
\hline Total & 4 & 7 & 2 & 3 & 1 & 17 \\
\hline
\end{tabular}

Table 10. Radiocarbon dates from the Istállóskő cave (AMS dates with italics, samples prepared by ultrafiltration technique are underlined)

\begin{tabular}{|c|c|c|c|c|c|}
\hline age, B.P. & lab. code & $\begin{array}{l}\text { archaeological } \\
\text { interpretation }\end{array}$ & stratigraphic interpretation & sample & reference \\
\hline $31.540 \pm 600^{78}$ & GrN-1501 & Aurignacian I. & grey debris layer 11 & charcoal & VOGEL-WATERBOLK 1963 \\
\hline $44.300 \pm 1.900$ & GrN-4659 & Aurignacian I. & bottom of the layer & bone & GEYH et al. 1969 \\
\hline $39.800 \pm 900$ & GrN-4658 & Aurignacian I. & upper part of the layer & bone & GEYH et al. 1969 \\
\hline $32.701 \pm 316$ & $I S G S-A-0187$ & Aurignacian I & $\begin{array}{l}-210 \mathrm{~cm} \text { (above the band of reddish } \\
\text { brown clay) }\end{array}$ & bone & ADAMS 2002 \\
\hline $33.101 \pm 512$ & $I S G S-A-0184$ & Aurignacian I.? & $\begin{array}{l}-260 \mathrm{~cm} \text { (below the band of reddish } \\
\text { brown clay) }\end{array}$ & bone & ADAMS 2002 \\
\hline $42.320 \pm 1.430$ & $?$ & $?$ & $?$ & $?$ & RINGER 2002, Fig. 2b \\
\hline $43.750 \pm 1730$ & $?$ & $?$ & $?$ & $?$ & RINGER 2002, Fig. 2b \\
\hline$\underline{34.890 \pm 250}$ & $O x A-X-2244-32$ & Aurignacian I. & "lower layer” & $\frac{\text { antler }}{\text { point }}$ & DAVIES-HEDGES 2011 \\
\hline$\underline{33.600 \pm 900}$ & $O x A-X-2180-18$ & Aurignacian I. & "lower layer" by Saád & $\frac{\text { antler }}{\text { point }}$ & DAVIES-HEDGES 2011 \\
\hline $30.900 \pm 600^{78}$ & GrN 1935 & Aurignacian II. & upper layer & charcoal & VOGEL-WATERBOLK 1963 \\
\hline $27.933 \pm 224$ & $I S G S-A-0186$ & Aurignacian II. & $-90-100 \mathrm{~cm}$ (bottom of hearth) & bone & ADAMS 2002 \\
\hline $31.608 \pm 295$ & $I S G S-A-0188$ & Aurignacian II.? & $\begin{array}{l}\text { dark brown clay with debris } \\
(-120 \mathrm{~cm})\end{array}$ & $?$ & ADAMS 2002 \\
\hline $29.035 \pm 237$ & $I S G S-A-0185$ & $?^{80}$ & $\begin{array}{l}\text { light brown clay with debris } \\
(-145 \mathrm{~cm})\end{array}$ & $?$ & ADAMS 2002 \\
\hline$\underline{30.970 \pm 310}$ & $O X A-16638$ & Upper Aurignacian & lower hearth $(-167 \mathrm{~cm})$ & bone & DAVIES-HEDGES 2011 \\
\hline $29.470 \pm 190$ & $O X A-16916$ & Upper Aurignacian & lower hearth $(-160 \mathrm{~cm})$ & charcoal & DAVIES-HedGES 2011 \\
\hline $29.240 \pm 170$ & $O X A-16917$ & Upper Aurignacian & lower hearth $(-160 \mathrm{~cm})$ & charcoal & DAVIES-HEDGES 2011 \\
\hline $30.510 \pm 170$ & $O X A-16093$ & Upper Aurignacian & upper hearth $(-141 \mathrm{~cm})$ & charcoal & DAVIES-HEDGES 2011 \\
\hline $29.900 \pm 190$ & OXA-16094 & Upper Aurignacian & upper hearth $(-141 \mathrm{~cm})$ & charcoal & DAVIES-HEDGES 2011 \\
\hline $24.950 \pm 140$ & $O x A-16640$ & & end of the cave $(-51 \mathrm{~cm})$ & bone & DAVIES-HEDGES 2011 \\
\hline $25.500 \pm 210$ & $\underline{O x A-16639}$ & & end of the cave $(-41 \mathrm{~cm})$ & $\underline{\text { bone }}$ & DAVIES-HEDGES 2011 \\
\hline
\end{tabular}

Levallois technology, ${ }^{81}$ which latter one is unknown in the assemblage under discussion. At the same time, we have a clear picture about the Proto or Early Aurignacian assemblages from the Carpathian basin (Transcarpathia, Banat ${ }^{82}$ ), the Wachau, ${ }^{83}$ or Eastern Europe, ${ }^{84}$ which have yielded lithic inventories basically different from the lower layer of

\footnotetext{
${ }^{78}$ A preliminary age of $30.670 \pm 500$ B.P. was published by VOGEL-WATERBOLK 1963.

${ }^{79}$ A preliminary age of $30.710 \pm 600$ B.P. was published in VÉRTES-DE VRIES 1959.

${ }^{80}$ The sample was collected between the two culture-bearing levels (AdAMs 2002, Table 1; Ringer 2002, Fig. 2b).
}

${ }^{81}$ TeYsSANDIER 2006, 10-14. - For an alternative interpretation of the Bacho Kiro material see: RIGAUD-LuCAS 2006.

${ }^{82}$ UsIK 2008; SitLIVY et al. 2012.

83 TEYSSANDIER 2006.

${ }^{84}$ DemidenKo 2009. 
the Istállóskő cave. As the typical forms are lacking from the studied assemblage, we can identify it as a non-typical blade industry with a single bifacially worked piece in agreement with the evaluations by Vértes and Simán. ${ }^{85}$

Surprisingly, the occurrence of this late tool was recently placed below the lower Aurignacian level, ${ }^{86}$ however, the only authentic report on the question unequivocally stated that the tool was found in the lower culturebearing layer ${ }^{87}$ Vértes suggested in the sixties that the Aurignacian and the Szeletian industries had lived independently and geographically separated in the Bükk Mountains and the 'leaf-point' was taken to the Istállóskö cave by the Aurignacian I. humans as a booty or as an unusual piece. This way the leaf-shaped tool from the Istállóskő cave and the split-based point from the Szeleta cave ${ }^{88}$ show only the contemporaneity of the industries. ${ }^{89}$ In the seventies, the monographic work of the osseous projectile points did not exclude the presence of a kind of Szeletian industry in the Istállóskő cave even as the producer of the bone industry as well, ${ }^{90}$ and most recently, the mixture of an Aurignacian and an underlying Szeletian layers was suggested in the sequence of the Istállóskő cave. ${ }^{91}$

As a matter of fact, the Szeletian industry as it is generally understood today, ${ }^{92}$ is absent not only from the Istállóskő cave but also from the eponymous site. ${ }^{93}$ At the same time, the presence of the leaf shaped scraper and the high number of retouched fragments in the Istállóskő assemblage shows certain similarities with the material of the Jankovich cave (Transdanubia) ${ }^{94}$ Although the presence or the relatively high ratio of radiolarite does not necessarily implies the same industry ${ }^{95}$ we have to mention that the leaf shaped tools, side-scrapers and fragmented retouched blanks from radiolarite were associated with osseous points, some of them split-based pieces, in the Jankovich and the Bivak caves (Transdanubia), ${ }^{96}$ in layer G1 of the Vindija cave (Croatia) ${ }^{97}$ and layer 11 of Dzeravá skála (Slovakia). .98 Without forgetting the serious stratigraphic problems and the debate even over the typological determination of the antler points from this later site, ${ }^{99}$ we suggested that at least the co-occurrence of 'Aurignacian'-type osseous tools on one hand and bifacially worked or Middle Palaeolithic lithics on the other is quite obvious in the Carpathian Basin. ${ }^{100}$ Our present results suggest that the 'Aurignacian I' assemblage of the Istállóskő cave should be interpreted the same way keeping in mind that the cultural determination is rather questionable because of the low number of diagnostic lithic tools. However, this site is the best preserved and the most promising locality for further investigations.

\section{STRATIGRAPHIC PROBLEMS IN THE ISTÁLLÓSKŐ CAVE - CASE STUDIES}

As we have discussed above the typical blade industry in the middle section of the cave found before World War II is characterised by an elevated ratio of an excellent quality raw material ('flint'), the presence of blunted elements, bipolar blade production and the dominance of uni- and bilaterally retouched blades. On the other hand, these artefacts are less abundant and the numerous 'archaic' tools (side scrapers and Mousterian points) were made of non-flint raw materials in the assemblage excavated in 1950-51. As the uppermost part of the sediment had been removed before the last excavations, certain stratigraphical differences could be supposed between the two groups of artefacts.

According to the data by Vértes, the large hearth with a stone construction, lifted in situ in 1947, was found $50 \mathrm{~cm}$ below the cave floor in the middle section of the cave, but regrettably, there are no exact data concerning the depth of the earlier trenches. Nevertheless, the recent reconstructions ${ }^{101}$ compared the stratigraphic position of this HÃO 2009, 408

${ }^{85}$ VÉRTES 1955, 120; SVOBODA-SiMÁN 1989, 310.

${ }^{86}$ SimÁN 1996, 45; TEYSSANDIER-LIOLIOS 2008, 739; ZIL-

87 VÉRTES 1961, 295: „Aus der unteren Feuerherdschicht haben wir aber eine typische Frühszeletien-[...] Blattspitze ans Tageslicht gebracht“ - See also: VÉRTES 1965, 174; 1968, 387.

${ }^{88}$ Hillebrand 1928.

${ }^{89}$ VÉRTES 1961.

${ }^{90}$ Albrecht et al. 1972, 71. - c.f. GÁBORI 1981, 102; GÁBORI 1982, 6.

${ }^{91}$ TEYSSANDIER-LIOLIOS 2008, 739.

${ }^{92}$ E.g. Oliva 1992, 36.

${ }^{93}$ SiMÁN 1990; MARKó 2009 b.

${ }^{94}$ MARKÓ 2013b.
${ }^{95}$ MARKó 2009. - Earlier the poorly defined and problematic Jankovichian industry was reported from several sites of the Bükk: Ringer 1983, 28-29, 124, Abb. 68; MeSter 2000; RingeRMester 2000, 267, Table 2. - c.f. MARKÓ 2013b.

${ }^{96}$ JÁNOSSY et al. 1957; MARKÓ 2013 b.

${ }^{97}$ KARAVANIĆ 1994.

${ }^{98}$ KAMinSKÁ et al. 2005, 45-50, 54, Fig. 18:1, 28:1-6.

99 BAYER 1927; PRošEK 1951, 296; PROŠEK 1953, 191 ; VÉrtes 1956b, 337; Brodar 1971, 50; ALLsWorth-Jones 1986, 122; KAMINSKÁ et al. 2005, 40, 54-55.

${ }^{100}$ MARKó 2013a.

${ }^{101}$ VÖRÖs 2003-2004, 40, 54. - Earlier the "big hearth" was placed into yellowish brown layer IV: VöRös 1984, 9. 
feature to the lower culture-bearing layer, which was first identified in 1950. From a typological point of view, however, the backed flint elements are fairly similar to the material excavated by Hillebrand. As an indirect datum we can cite the notes on the 1917 season when three large and flat stone slabs were found on the bottom of the 'hearth level', ${ }^{102}$ very similar ones to the hearth found by Vértes. This is why it seems to be the most plausible to link the hearth and the artefacts to this industry.

The next question is the stratigraphical-chronological relation between the flint-dominated typical blade industry excavated in 1912-1947 and the assemblage of the 'upper layer' of Vertes. The majority of the artefacts found by Hillebrand were collected from the 'large hearth level', but there are no precise stratigraphical data for any of the artefacts found before the World War II including the few 'archaic types' from limnic quartzite and felsitic porphyry. One of the most beautiful flint artefacts found by Vértes (Fig. 4.7) is practically a stray find as it was collected during the cleaning of the cave floor (i.e. the bottom of the trench by Hillebrand or Kadić) before the excavations of trench IV-VI, and the majority of the stratified flint artefacts were documented in trench III and VI right next to the northern wall of the cave, suffering all the above mentioned stratigraphic problems. Although the conjoinable pieces of refit groups 3 and 10 (Fig. 4.8; 5.3) show that at least a few pieces excavated in the 1910s and in 1950 belong to the same assemblage, it remains possible, that the Upper Palaeolithic and the 'archaic' types or the flint and non-flint artefacts were originally deposited in discrete and partly overlapping lithological and cultural levels. If we look closer at the documentations we find, however, that the blunted blade excavated in the fifties (Fig. 6.5) was found in the 'upper hearth layer' in trench III in close association with the limnic quartzite core of refit group 17 (Fig. 7.4), the fragment of a side scraper from limnic quartzite (Fig. 8.4) and the half-made bifacial tool from felsitic porphyry (Fig. 6.1). The presence of an 'archaic side scraper' 103 from the overlying 'Magdalenian' layer IV and a double scraper (Fig. 8.5) found at the border of the Upper and Lower cultural-bearing layers shows that a certain mechanical mixing is not impossible, however, the contemporaneity (see infra) of the pieces is obvious. The same is true for trench VI, where a typical Mousterian point from radiolarite (Fig. 8.2) was found in the same place and depth as a weathered antler point, ${ }^{104}$ a unilaterally retouched blade from silicified wood (Fig. 4.4) and an atypical crested blade. ${ }^{105}$

Another aspect of the same problem is the question of discrete cultural levels in the sedimentary units. ${ }^{106}$ On the sections published by Vértes, ${ }^{107}$ two discrete artefacts bearing levels are indicated in layer III, however, the fragments of a radiolarite blade were found in both the upper and the lower level of this unit (refit group 7: Fig. 7.2). Moreover, two blade fragments from the upper level were joined to pieces uncovered at the northern wall of the cave (trench $\mathrm{X}$ ): one of them in the overlying yellowish brown loessy clay layer IV (refit group 16: Fig. 7.1), the other one (group 13: Fig. 7.3) at the border of layers I and III (i.e. the upper and lower culture-bearing layers). Importantly this latter piece was sorted to the assemblage of the upper culture layer in the field notes following merely morphological considerations and not stratigraphical observations.

We suggest as a conclusion that all the artefacts documented in layer III and at least a few pieces from the overlying layer $\mathrm{IV}^{108}$ may belong to a single assemblage (possibly with intrusive pieces from the underlying layers $^{109}$ ) irrespective of the raw material or the typological classification of the artefacts. With other words, our studies simply have not supported the existence of discrete culture-bearing levels in the upper ('Aurignacian II') layer of the Istállóskő cave. ${ }^{110}$

Finally, we have to shortly discuss the stratigraphic position of the leaf point (Fig. 6.3), because it was recently suggested that it had been found between the two culture-bearing layers. ${ }^{111}$ As a matter of fact, a consider-

${ }^{102}$ Hillebrand 1919a, 10, 41.

${ }^{103}$ VÉRTES 1955, 128, Taf. L: 6.

104 VÉRTES 1955, Taf. XLII: 12; Dobosi 2002, 90, Inv. nr

Pb.51/92.

105 VÉRTES 1955, Taf. XLVI: 7

106 VÖRÖS 1984; RINGER 2002, 51.

${ }^{107}$ VÉRTES 1955, Fig. 3b, Taf. LIb.

${ }^{108} \mathrm{~V}$. Dobosi suggested that a typical bone item found in the

'Magdalenian' layer was mixed in from the lower layers: DoBosi 2002, 89.

${ }^{109}$ At least one split based point was certainly found in the

Upper culture-bearing layer, supposedly as the consequence of biotur- bation: VÉRTES 1955, 124, Taf. LII,3. - V. Dobosi sorted three further fragments inventorised as belonging to the upper culture-bearing layer to the Aurignacian I assemblage: DoBosi 2002, 99, inv. nr Pb.50/155157 and $\mathrm{Pb} .50 / 159$.

${ }^{110}$ Importantly, Fig. 2B of the publication by RINGER (2002) depicted only Aurignacian I and II layers, without discrete levels.

${ }^{111}$ SimÁn 1996, 45; MESTER 2014, 165. - During the 2000 excavations, another bifacial tool was found ,,between the two dated stratigraphic units" (with ages of 28-33 kys): ADAMS 2002, 55; ADAMS-RINGER 2004, 548. - In fact, however, there was no sterile sediment between the 'lower' and the 'upper culture-bearing layers' in trench VIII by Vértes. 
able gap was observed between the formation of layers I and III $^{112}$ indicated by fragments of lithostratigraphic units as the 31.5 kys old (Table 10) grey debris layer in the northern part of the cave, the 'reddish wedge-shaped inclusion' in the southern one, the dark brown lens with microfauna at the entrance ${ }^{113}$ or two cave loess layers ${ }^{114}$ in the trench of the last excavations. Regrettably, the details of the recovery of the leaf-shaped point were not recorded, ${ }^{115}$ however, according to each publication by the excavator, the piece was found in a well identifiable place of the cave far from the above mentioned residuals of stratigraphic units and clearly in layer III (i.e. in the Upper layer ${ }^{116}$ ), which directly overlappes layer I (i.e. the lower culture-bearing layer).

\section{PROBLEMS WITH THE CULTURAL DETERMINATION OF THE ‘UPPER LAYER’}

Before World War II, the industry of the Istállóskő cave was affiliated to the 'upper Aurignacian' or the late phase of the 'Middle Aurignacian' culture and it was compared to the assemblages of Willendorf and Moravány, ${ }^{117}$ which belong to the Gravettian circle according to the modern terminology. ${ }^{118}$ Since 1955 , the assemblage of the upper layer has been identified as Aurignacian II industry, ${ }^{119}$ or the older phase of the same entity ${ }^{120}$ in spite of the lack of typical lithics (carenoid pieces and bladelets). ${ }^{121}$

On the other hand, seven backed bladelets were unearthed in the Istállóskő cave in 1912-1951 and further two were left the surface of the exhibited large hearth although blunted elements are quite rare in the s. str. Aurignacian assemblages. ${ }^{122}$ This, together with the presence of bipolar blade cores suggests that the lithic assemblage excavated by Hillebrand and Vértes in the middle and the front section of the cave show connections with the Gravettian circle. We refer to the Bodrogkeresztur-Henye site, ${ }^{123}$ where steeply retouched elements and unilaterally retouched blades are well represented, and 'archaic' pieces, including Mousterian points are also present. ${ }^{124}$

The other characteristic group of finds in the Istállóskő cave, the leaf-shaped implements are also regarded as non-Aurignacian elements, ${ }^{125}$ but beside the leaf-shaped point fragment (Fig. 6.3), half made tools from felsitic porphyry (Fig. 6.1) and radiolarite (Fig. 6.2) show that bifacial processing was not exceptional in the assemblage excavated by Hillebrand and Vértes. Moreover, leaf-shaped tools have long been known from Aurignacian open-air sites in the Košice basin, in the Vihorlát ${ }^{126}$ and in the Oaş mountains, ${ }^{127}$ and leaf-shaped tools have been reported from the recently discovered site of Acsa (Cserhát area, northern Hungary) ${ }^{128}$ too.

Taking into consideration that leaf-shaped implements have also been reported from typical Gravettian ${ }^{129}$ localities and the 'upper layer' of the Szeleta cave yielded a basically Gravettian assemblage with leaf shaped

112 VÉRTES 1965, 174

${ }^{113}$ VÉRTES 1955, 112, Abb. 3, Taf. LI.b.

${ }^{114}$ Stratigraphic units $f$ and $h$ : RINGER 2002, Fig. 2. - c.f. VÉRTES 1955, Abb. 3b.

115 See note 16

116 VÉRTES 1955, 126: "Sie kam im nördlichen Teil von Block IV, in der oberen Kulturschicht, unter einem gewaltigen Tropfsteingebilde zum Vorschein." - see also: VÉRTES 1965, 175; VÉRTES 1967, 308; VÉRTES 1968, 387.

${ }^{117}$ Hillebrand 1913; Hillebrand 1917, 108; Hillebrand 1919, 10-13; Hillebrand 1919b, 25-26; HilleBRAND 1934/35, 1920; Hillebrand 1935, 15; KAdić 1934, 74-77; MotTl 1942, 89-91.

${ }^{118}$ Interestingly, VÉRTES (1956a, 338) compared the Late Aurignacian (i.e. Gravettian: MARKó 2011, 96, fn. 10) industry from the Dzeravá skála / Pálffy cave to the Aurignacian II assemblage in the fifties. At the same time, M. GÁBORI (1958) refused any connections between the Gravettian culture and the Istállóskő cave, however, the assemblages analysed by him are identified today as Epigravettian and Ságvárian assemblages. Finally for the recent identification the Istállóskő upper layer as Gravettian see: ALBRECHT et al. 1972, 71-72.

${ }^{119}$ See note 5.

${ }^{120}$ BÁNESZ 1976, 64.

${ }^{121}$ In the monograph of 1955 two atypical high scrapers were mentioned. One of them (VÉRTES 1955, 126, Taf. XLV, 8) is in fact a retouched blade, the other one was refitted to a typical blade point (VÉRTES 1955, 126, Taf. XLVII, 2. - c.f. refit group 3: Fig 5, 3).

122 The pieces e.g. from layer $3 \mathrm{~g}, 3 \mathrm{~h}$ in Temnata cave, Bulgaria are considered as intrusive elements (similarly to the blunted bladelet from the Dzeravá skála cave, Slovakia: KAMINSKÁ et al. 2005, 41 ), or they are compared to the assemblages in northern Italy (KoZŁowsKi 1999, 108-110).

${ }^{123}$ In some recent works the typological classigication of this site was questioned: LENGYEL 2014, 334. - In the same work the Istállóskö cave was classified as Early Gravettian, with a reference to the abstarct book of the Vienna 2008 conference; the lithic analysis of this unpublished work was carried out by the author of the present paper.

${ }^{124}$ Dobosi 2000, 46.

${ }^{125}$ But see: AdAMS 2007, 97; KozŁowSKI et al. 2009, 448-449.

${ }^{126}$ KAMINSKÁ 1990a; KAMINSKÁ 1990b. - From the earlier phase of the industry, represented in Barca II, complex II a surfaceretouched piece was compared to the Szeletian types (BÁNESZ 1968, 158, Abb. 46:16).

${ }^{127}$ Boineşti and Remetea: BITIRI 1972, 30-41.

${ }^{128}$ Dobosi 2008.

129 Trenčianske Bohuslavice and Hont(?): BÁRTA 1988; Dobosi-Simán 2003. 
points, ${ }^{130}$ we suggest that bifacially worked pieces and preforms should be regarded as integral elements of the upper layer of the Istállóskő cave not only from a stratigraphical but also from a cultural point of view.

An important assemblage of the Late Aurignacian was excavated in pit 3 of the open-air site of Bárca I in the Košice basin, eastern Slovakia, where several large hearths with stone structures, similar to the Istállóskő feature were also documented. ${ }^{131}$ The composition of the lithic inventory, the presence of bifacially worked tools (including a half-made piece ${ }^{132}$ ), burins made on truncations ${ }^{133}$ and side scrapers from felsitic porphyry ${ }^{134}$ all remind us of the assemblage excavated by Hillebrand and Vértes. However, the number and the ratio of blunted bladelets (15 pieces, i.e. $8.67 \%$ of the inventory ${ }^{135}$ ) are higher than in the Istállóskő cave, and the retouched blades or the side scrapers in Bárca seem to be quite atypical pieces. Finally, the high number of unretouched bladelets and flake cores, ${ }^{136}$ the presence of dihedral burins and especially of carenoid end-scrapers clearly shows the differences from the upper layer of the Istállóskő cave.

Finally, the small material found by Saád, Mottl and Vértes in the rear part of the Istállóskő cave, which also suffers from serious stratigraphical problems, is also grouped into a basically Gravettian industry according to the presence of blunted elements (fragments of Gravette points, first mentioned from this part of the Istállóskö cave $\left.{ }^{137}\right)$. Moreover, the conical blade core from obsidian excavated by Mottl is a typical Gravettian form in Hungary. ${ }^{138}$

\section{METHODOLOGICAL OBSERVATIONS}

During our work we were confronted with the serious problems of evaluating the 'classical' assemblages of the early excavations. ${ }^{139}$ The main problem is that the basic technical units of these excavations were very rough as compared to the modern documentation methods. The observations in trench VIII in the Istálóskö cave, which was documented in 10-20 cm thick levels show that a careful excavation strategy would have led to significantly larger assemblages along with better stratigraphical data - even in the first years of the 1950s.

Surprisingly few artefacts were found during the long history of the excavations, e.g. the 160 square meters of Vértes's trenches yielded only 297 pieces: 143 of them are from bone, antler or ivory and 154 items are lithics. These figures mean 0.9-1 pieces in a square meter regarding the total thickness of the cave infilling. This low density of the archaeological material is not unusual in cave sites either in Hungary ${ }^{140}$ or on other territories (e.g. the Balkan Peninsula ${ }^{141}$ ) and that was why M. Mottl finished working in the Istállóskő cave. ${ }^{142}$

All the available data show that no discrete archaeological levels or living floors can be reconstructed in the Istállóskő cave. ${ }^{143}$ Thus our results are in contradiction with the recent evaluation, which reconstructs seasonal and permanent settlements in different parts of the 'upper culture layer'. ${ }^{144}$ Moreover, the hypothesis of the existence of temporary summer-fall satellite hunting stations of groups of 15-20 persons in the two levels of the "lower hearth and culture-bearing layer ${ }^{1} 145$ also seems unacceptable when compared to the few archaeological artefacts. Finally, the autumn-summer seasonal camp in the entrance of the cave or the permanent settlement with meat and fur depot

\footnotetext{
${ }^{130}$ SimÁn 1990, 192. - On the question of the blunted pieces found in the Szeleta cave see also: RINGER-MESTER 2000.

${ }^{131}$ BÁNESZ 1968, 34, Abb. 16, Taf. III.

${ }^{132}$ Made from felsitic porphyry and radiolarite: BÁNESZ 1968, 142, Abb. 31:5, 31:1, 3.

${ }_{133}$ BÁNESZ 1968, 139.

${ }^{134}$ BÁNESZ 1968, 142, Abb. 36: 21 4, 37:3, 4.

${ }^{135}$ BÁNESZ 1968, 147.

${ }^{136}$ Mentioned by HAHN 1977, 194.

${ }^{137}$ SAÁD 1927.

${ }^{138}$ E.g. Bodrogkeresztúr: Biró 1984, Fig. 12:1, 8, 9. - A very similar piece was published from the upper culture-bearing layer of the Szeleta cave: KADIĆ 1915b, 127, fig. 39.

${ }^{139}$ The questions emerged even 30 years after the excavations were discussed by DibBLe et al. 2005. For a more optimistic approach of the very old excavated sites see: MESTER 2001.
}

${ }^{140}$ E.g. the several thousands of excavated cubic meters of the infilling of the Szeleta cave yielded only 2000 artefacts untill 1913: RINGER-SZOLYÁK 2004, 16-17.

${ }^{141}$ KoZŁowsKi 1999, 112-113.

${ }^{142}$ KADIĆ-MotTl 1944, 37.

${ }^{143}$ Even the successful refits do not necessarily verify the existence of living floors, as in the case of layer 7 in Potočka zijalka: BRODAR 1985, 77.

${ }^{144}$ VöRös 2003-2004, 66-67. - In the earlier works this layer was interpreted as a fall-winter-spring periodic base camp with groups of 20-25 persons in each of the three "hearth and culture-bearing levels': VöRös 1984.

${ }^{145}$ The permanent settlement, supposed in the second half of the cave (with traces of "bear cult") is a clear consequence of the stratigraphic evaluation of the 'large hearth' and the 'cultic place'. 
in the 'Magdalenian' layer IV (yellowish brown loessy clay) ${ }^{146}$ is not verified by the very scarce artefact material, which partly belongs to the 'upper layer' (refit group 16) and partly to a more recent Prehistoric period. ${ }^{147}$

Our results suggests that the assemblages are traces of short and very short term occupations, possibly hunting stations, hidden at the end of the long and deep Szalajka valley, at a relative height of $80 \mathrm{~m}$; this is supported by the high number of osseous points and one-sided lithic tool-kits. The scarcity of artefacts and the very few traces of primary flaking can make the search for similar assemblages complicated as the typological composition of the collections and even the presence of certain tool types (backed elements, 'archaic' tools etc.) may imply a characteristic 'functional facies' and not a special archaeological culture or industry. ${ }^{148}$

Instead of the 'occupational contemporaneity' suggested by N. Conard and D. Adler ${ }^{149}$ in our earlier paper ${ }^{150}$ we use the term 'observational contemporaneity' for describing the connections of the lithic and osseous artefacts in cave localities. This way we do not assume that the pieces belong to a single occupation event but recognise that the available field observations do not permit to separate the artefacts into different collections, irrespective of the circumstance that the time that passed between the burial of two artefacts could be 15 hours or 15 years. ${ }^{151}$ To put it another way, the quality of the available documentations and the results of the analysis do not allow us to confirm the a priori expectations (e.g. the stratigraphical position and the role of the leaf-shaped implements). ${ }^{152}$

\section{CONCLUSIONS}

At the present state of investigations of the Istállóskő assemblages, our results listed in Table 3-10 can be summarised as the followings:

1. The analysis of the artefacts from the site and especially from reference trench VIII excavated by Vértes shows obvious traces of post-sedimentation disturbances in the cave infilling, probably linked among others with cave bears activities, falling rocks, frost and flowing water, or pits dug in Prehistoric and historic ages, diggings by fossil and treasure hunters and not systematic excavations. At the same time, the differences in the patina formation on the same artefact (refit groups 1, 4 and 5), the presence of almost intact cave bear skeletons ${ }^{153}$ and layers of charcoal or ash indicate that the intensity of disturbance was extremely varied in different parts of the cave and the layer sequence, which calls for certain doubts regarding the simplistic chronological and archaeological interpretation of the site as a whole.

2. We have to stress that typical Aurignacian type lithics are absent from each culture-bearing layer of the Istállóskő cave, so the industries cannot be grouped into this Early Upper Palaeolithic entity. Although bidirectional core exploitation was also used in Central Europe, namely, in Moravia, ${ }^{154}$ and bladelets are generally missing from the Central European 'Aurignacoid' assemblages, ${ }_{155}^{15}$ even the minimal synapomorphy, the carenoid pieces are absent in the Istállóskő cave. The presence of bifacial tools and backed elements in the upper culture-bearing layer also suggests a different classification. Keeping in mind that the presence of an 'early' osseous industry is not a unique phenomenon of this entity since it has been demonstrated in leaf-point industries in a large part of Central Europe ${ }^{156}$ we can conclude that thare is no solid base for identifying the cave as an Aurignacian site.

3. The first occupation of the cave, dated from around $>35-33$ kys according to the not calibrated radiocarbon chronology, is linked to a not typical blade industry with heavily retouched fragmented blanks ('raclettes') and a leafshaped scraper, associated with numerous osseous points, including split-based pieces. This typological spectrum shows certain similarities to the assemblages from the Jankovich, Bivak and Vindija caves. Another group of artefacts

\footnotetext{
${ }^{146}$ VÖRÖS 2003-2004, 67.

${ }^{147}$ Two 'pearls of stone' were reported from the 'Magdalenian' light brown clay: KaDIĆ-MotTL 1944, 40-41.

${ }^{148} \mathrm{On}$ the interpretation of the Aurignacian and Olschewian entities see: VALOCH 1968, 35 with comments by Fr. Bordes, H. Delporte and J. Neustupný (idem, p. 369, 371 and 381) and a reply by Valoch (p. 387).

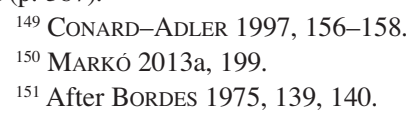

${ }^{152}$ On the other hand, to co-occurrence of 'archaic' and blade tools, or bifacial implements in the same excavation unit at least calls for certain doubts on the validity of the pure typological and technological approaches, allowing to define four or five industries within small materials collected on the surface or in single layers of a cave without stratigraphical or planigraphical data: e.g. KozŁowsKI $e t$ al. 2009; RINGER-MESTER 2000

${ }^{153}$ JÁNOSSY 1955, 157.

${ }^{154}$ Oliva 1984; NerUdA-Nerudová 2005, 280-282, 288.

${ }^{155}$ SvoBoda 2006, 263-264.

${ }^{156}$ MARKó 2013a. 
that may become important for future investigations was discovered at the open-air localities around Velky Šariš, eastern Slovakia, where a radiolarite blade industry was collected together with bifacial tools, ${ }^{157}$ however, there are no detailed descriptions of the non-bifacial lithics from this site and the osseous artefacts are missing from the inventory.

4. The assemblage, excavated in the middle section of the cave before 1950 is considered as a typical, although not Aurignacian-type blade industry. The dominance of retouched blades among the formal tools, the presence of bipolar core technique and blunted elements suggest connection with the Gravettian circle, however, the $31-28$ kys old radiocarbon dates from this layer seem to be slightly too early for this classification. According to our refit studies, the stratigraphic and planigraphical data, the assemblage of the upper culture-bearing layer excavated in 1950-51 with Middle Palaeolithic and bifacial tools and the scarce Olschewa/Mladeč-type bone industry belong to the same entity. ${ }^{158}$ We suggest that the differences in the typological composition of the assemblages excavated before and after 1948 are due to the not homogenous spatial distribution of the artefacts made from different row materials and to a certain raw material preference for producing special tool types. The same dichotomy was observed in the rear part of the cave, where two fragmentary transversal scrapers made from non-flint raw materials, namely limnic quartzite and obsidian were found. As a conclusion, we suggest certain connections with the Gravettian sites from where 'archaic' types have been reported (e.g. Bodrogkeresztúr), the supposed Gravettian assemblage of upper layer of the Szeleta cave, and certain eastern Slovakian 'Aurignacian-type' industries, especially Bárca II.

5. In the light of the data concerning the stratigraphical and planigraphical positions of the bifacially worked pieces and the blunted elements in the Istállóskö cave, the nature of the connections between the eastern and the western parts of the Bükk Mountains should be reconsidered after the detailed publication of the archaeological and stratigraphical revisions of the Szeleta cave. ${ }^{159}$

6. Keeping in mind that the field observations reflect at least sixty years old preferences and there are numerous obscure points in the documentations as it has been mentioned above ${ }^{160}$ our classification is rather tentative and should be used as a working hypothesis and not as a useful base for answering our actual questions. Further studies are necessary, first regarding the open-air sites ${ }^{161}$ in the vicinity of the cave and next on farther territories from where similar archaeological materials have been reported. ${ }^{162}$

7. Finally, the most promising place for testing our results lies in the middle section of the cave close to trench VIII by Vértes, at the same place where the test trench was opened by Ringer and Adams. The occurrence of bifacial tools (found in 1958 and 2000), osseous artefacts (among others, split-based points from both the upper and the lower culture-bearing layer or the ivory amulet from the latter one) and the refitted blades may offer a possibility for clearing at least some of the stratigraphical and chronological questions or the problems of the site formation and the cultural classification. However, only excavations on a large surface seems to be reasonable because of the scarcity of the artefacts.

\section{ACKNOWLEDGMENTS}

The study was supported by the Hungarian Scientific Research Fund (OTKA K 100385: Provenance study of lithic raw materials of stone tools found in the Carpathian Basin).

The author is grateful to Tom Higham for his useful comments on the radiocarbon dates from the site.

${ }^{157}$ BÁNESZ 1960; BÁNESZ 1961.

${ }^{158}$ As we have mentioned above, Gy. Lengyel $(2014,334$, Fig. 7) recently grouped the assemblage of the upper layer of the Istállóskő cave to the Early Gravettian period (however, in the same paragraph, he stated that 'a very early Gravettian presence in Hungary cannot be firmly argued') and grouped layer 5 and 6 of the Szeleta cave and Hont-Parassa III into a late Gravettian variant with leaf shaped points. The weakness of this classification is obvious as the bifacial tools were found in clear stratigraphic position in the Istállóskó cave together with backed implements and they are associated with radiocarbon ages that imply the Early Gravettian period and even older ones. Taking into consideration that the detailed analysis of the Szeleta assemblages (first linked to the Gravettian circle by SIMÁN 1990, 192) and the one from Hont, placed by the excavators to the Pavlovian period is not yet published, we conclude that there does not exist a well defined late Gravettian industry with leaf points in Hungary.

${ }^{159}$ Ringer-MESTER 2000; RINGER 2002; RINGER-SZOLYÁK 2004

${ }^{160}$ The strangest point is the fate of the artefacts and fossils excavated in 1929 by O. Kadić.

${ }^{161}$ As it was suggested nearly 70 years ago: MotTL 1942, 89.C.f. MAJER 1920, 20-23.

${ }^{162}$ E.g. Hont-Kutyika: GÁBORI 1958, 59-60; Bánat-utca: Simán 1993, 249, Fig. 2.5; Ipolyság: Majer 1920; Hillebrand 1934/35, 19; 1935, 20. 


\section{REFERENCES}

ADAMS 1998

ADAMs 2002

ADAMS 2007

ADAMS-RINGER 2004

AlBRECHT et al. 1972

ALLSWORTH-JONES 1986

BÁNESZ 1960

BÁNESZ 1961

BÁNESZ 1968

BÁNESZ 1976

BÁRTA 1988

BAYER 1927

BIRÓ 1984

BIRÓ 1998

BIRÓ-DOBOSI 1991

BITIRI 1972

BORDES 1975

BRODAR 1971

BRODAR 1985

CONARD-ADLER 1997

DAvies-Hedges 2011

DEMIDENKo 2009

DiBBLE-RACZEK-MCPHERRON 2005

DoBosi 1975

Dobosi 2000

Dobosi 2002

Dobosi 2008
= B. AdAms: The Middle to Upper Paleolithic Transition in Central Europe: The record from the Bükk Mountains region. BAR IntSer 693. Oxford 1998.

= B. ADAMS: New radiocarbon dates from Szeleta and Istálló-kő caves, Hungary. Praehistoria 3 (2002) 53-55.

= B. AdAms: Gulyás archaeology: The Szeletian and the Middle to Upper Palaeolithic transition in Hungary and Central Europe. In: New Approaches to the Study of Early Upper Palaeolithic 'Transitional' Industries in Western Eurasia. Transitions great and small. Eds. by J. Riel-Salvatore, G. A. Clark. BAR IntSer 1620. Oxford 2007, 90-110.

= B. ADAMS-Á. RingER: New C14 dates for the Hungarian Early Upper Palaeolithic. Current Anthropology 45 (2004) 541-551.

$=$ G. AlBreChT-J. HAHN-W. C. Torke: Merkmalanalyse von Geschossspitzen des mittleren Jungpleistozäns in Mittel- und Osteuropa. Archaeologica Venatoria 2. Stuttgart 1972.

$=$ Ph. Allsworth-Jones: The Szeletian and the Transition from Middle to Upper Palaeolithic in Central Europe. Clarendon Press, Oxford 1986.

= L. BÁNESZ: K otázke listovitých hrotov z Vel'kého Šariša (A la question des pointes foliacées de Vel'ký Šáriš en Slovaquie). AR 12 (1960) 313-318.

= L. BÁNESZ: Zist'ovaci výskum na paleolitickej stanici vo Vel'kom Šariši roku 1960 (Eine Probegrabung auf der paläolithischen Station in Vel'ký Šariš im Jahre 1960). ŠtZ 6 (1961) 255-227.

= L. BÁNESZ: Barca bei Košice - Paläolithische Fundstelle. Bratislava 1968.

= L. BÁNESZ: Prírodné prostredie, hospodárska základňa a materiálna kultúra Aurignacienu strednej Európy (Natürliches Milieu, wirtschaftliches Basis und materielle Kultur des Aurignacien Mitteleuropa). SlA 24 (1976) 5-82.

= J. BÁRTA: Trencianske Bohuslavice, un habitat Gravettien an Slovaquie occidentale. L'Anthropologie (Paris) 92/4 (1988) 173-182.

= J. BAYER: Die Olschewakultur eine neue Fazies des Schmalklingenkulturkreises in Europa. Eiszeit und Urgeschichte 6 (1929) 83-100.

$=\mathrm{K}$. BIRÓ: Distribution of obsidian from the Carpathian sources on Central European Palaeolithic and Mesolithic sites. AAC 23 (1984) 5-42.

$=$ K. BIRó: Lithic Implements and the Circulation of Raw Materials in the Great Hungarian Plain during the Late Neolithic Period. Budapest 1988.

= K. Biró-V. Dobosi: Lithotheca. Comparative Raw Material Collection of the Hungarian National Museum. Budapest 1991.

= M. BITIRI: Paleoliticul în Ţara Oaşului - Studiu arheologic [Palaeolithic in Ţara Oaşului - Archaeological study]. Bucureşti 1979.

= F. BORDES: Sur la notion de sol d'habitat en préhistoire paléolithique. BSPF 72/5 (1975) 139-144.

$=$ M. BRODAR: Olschewien. Die Anfangssufen des Jungpaläolithikums in Mitteleuropa. Actes du VIII ${ }^{\mathrm{e}}$ Congrès International des Sciences Préhistoriques et Protohistoriques, Beograd, 9-15 septembre 1971. Réd. par M. Garašanin, A. Benac, N. Tasić. Beograd 1971, I, 43-52.

= M. BRODAR: Die Höhlen Potočka zijalka und Mokriška jama. Quartär 35/36 (1985) 69-80.

$=$ N. CONARD-D. AdLER: Lithic reduction and hominid behavior in the Middle Palaeolithic of the Rheinland. Journal of Anthropological Research 53 (1997) 147-175.

= W. Davies-R. Hedges: Dating a Type Site: Fitting Szeleta into its regional chronometric context. Praehistoria 9-10 (2008-2009) 35-45.

= Yu. Demidenko: Orinjak bol'shogo cevernogo Prichernomorya: obzor obshchih i osobennyh industrial'no-hronologicheskih harakterictik [The Great North Black Sea region Aurignacian: an overview of common and particular industrial-chronological characteristics]. In: Aktyalnae problemy pervobytnoi arheologii vostochnoi Evropy. Ed.: V. P. Chabai. Arheologicheskij al'manah 20. Donetsk 2009, 159-186.

= H. L. Dibble-T. P. RaczeK-S. P. McPherron: Excavator bias at the site of Pech de l'Azé IV, France. JFA 30/3 (2005) 317-328.

= V. Doвosi: Magyarország ős- és középsőkőkori lelőhely katasztere (Register of Palaeolithic and Mesolithic sites in Hungary). ArchÉrt 102 (1957) 64-76.

= V. Doвosi: Archaeological investigations at Bodrogkeresztúr-Henye. In: Bodrogkeresztúr-Henye (NE-Hungary) Upper Palaeolithic Site. Ed.: V. Dobosi. Budapest 2000, 5-111.

= V. Doвosi: Bone finds from the Istállóskő Cave. Praehistoria 3 (2002) 79-102.

= V. Dobosi: Acsa: new open-air Aurignacian site in Hungary. In: Man - Millenia - Environment. Studies in honour of Romuald Schild. Eds: N. Z. Sulgostowska, A. J. Tomaszewski. Warsaw 2008, 151-159. 
DoBosi-SimÁn 2003

FÜLÖP 1994

GÁBORI 1964

GÁBORI 1969

GÁBORI 1958

GÁBORI-CsÁNK 1970

GEYH et al. 1969.

GINTER-KOZŁOWSKI 1982

HAHN 1977

HiLLEBRAND 1913

HiLlebrand 1914

HiLlebRAND 1917

HILLEBRAND 1919a

Hillebrand 1919b

HiLLEBRAND 1926

HILLEBRAND 1928

HiLlEBRAND 1934-1935

HiLLEBRAND 1935

JÁNOSSY 1955

JÁNOSSY et al. 1957

KADIĆ 1915a

KADIĆ $1915 b$

KADIĆ 1934

KADIĆ-MotTL 1944

KAMINSKÁ 1990a

KAMINSKÁ 1990b

KAMINSKÁ 1991

KAMINSKÁ et al. 2005

KARAVANIĆ 1994

KASZTOVSZKY et al. 2008

KISS 1958
= V. Dobosi-K. Simán: Hont-Parassa III, Orgonás, Upper Palaeolithic settlement. ComArchHung 2003, 15-29.

= J. FüLÖP: Magyarország geológiája - Paleozoikum II [Geology of Hungary - The Palaeozoic era II]. Budapest 1994.

= M. GÁBORI: A késői paleolitikum Magyarországon [The Late Palaeolithic in Hungary]. RégTan 3. Akadémiai Kiadó, Budapest 1964.

= M. GÁBORI: Regionale Verbreitung paläolithischer Kulturen Ungarns. ActaArchHung 21 (1969) $155-165$.

= V. GÁBori: Neue paläolithische Funde im Eipel-Tal. AR 10 (1958) 55-61.

= V. GÁBORI-CSÁNK: C-14 dates of the Hungarian Palaeolithic. ActaArchHung 22 (1970) 1-11.

= M. A. GEYH-F. SCHWEITZER-L. VÉRTES-J. C. VOGEL:A magyarországi würmi eljegesedes új kronológiai adatai (Neue chronologische Angaben der Würm-Vereisung in Ungarn). FöldrÉrt 18 (1969) 5-18.

= B. GinTeR-J. K. KozŁowski: Conclusions. In: Excavation in the Bacho Kiro Cave. Final Report. Ed.: J. K. Kozłowski. Warszawa 1982, 169-172.

= J. HAHN: Aurignacien. Das ältere Jungpaläolithikum in Mittel- und Osteuropa. Köln-Wien 1977.

= J. Hillebrand: A pleistocaen ősember ujabb nyomai hazánkban (Neuere Spuren des diluvialen Menschen in Ungarn). Barlangkutatás 1 (1913) 19-25, 46-52.

= J. HilleBRAND: Az 1913. évi barlangkutatásaim eredményei (Ergebnisse meiner Höhlenforschungen im Jahre 1913). Barlangkutatás 2 (1914) 115-124, 147-153.

= J. HiLlebrand: Az 1916. évi barlangkutatásom eredményéröl (Über die Resultate meiner Höhlenforschungen im Jahre 1916). Barlangkutatás 5 (1917) 98-108, 125-130.

= J. HiLlEBRAND: Az 1917. évben végzett ásatásaim eredményei (Resultate meiner Ausgrabungen im Jahre 1917) Barlangkutatás 7 (1919) 6-13, 39-41.

= E. Hillebrand: Das Paläolithikum Ungarns. Wiener Praehistorischen Zeitschrift 6 (1919) 14-40.

= J. HiLLEBRAND: Über neuere Funde aus dem ungarländischen Paläolithikum. Die Eiszeit 3 (1926) 3-5.

= J. HILLEBRAND: Über eine neue Aurignacien-Lanzenspitze ,à base fendue" aus dem ungerländichen Paläolithikum. Eiszeit und Urgeschichte 5 (1928) 99-103.

= J. HiLlEBRAND: Der Stand der Erforschung der älteren Steinzeit in Ungarn. BRGK 24/25 (1934/35) $16-26$.

= J. HiLlebrand: Magyarország őskőkora (Die ältere Steinzeit Ungarns). ArchHung 17. Budapest 1935.

= D. JÁNOSSY : Die Vogel- und Säugetierreste der spätpleistozänen Schichten der Höhle von Istállóskő. ActaArchHung 5 (1955) 149-181.

= D. JÁnOsSY-S. Kretzoi-VArRóK-M. Herrmann-L. Vértes: Forschungen in der Bivakhöhle, Ungarn. Eiszeitalter und Gegenwart 8 (1957) 18-36.

= O. KADIĆ: Jelentés a Barlangkutató Szakosztály 1914. évi működéséről (Bericht über die Tätigkeit der Fachsektion für Höhlenkunde im Jahre 1914). Barlangkutatás 3 (1915) 12-20, 32-39.

= O. KADIĆ: A Szeleta-barlang kutatásának eredményei [Results of the investigations in the Szeleta cave]. A Magyar Királyi Földtani Intézet Évkönyve 23/4 (1915) 151-278.

= O. KADIĆ: Der Mensch zur Eiszeit in Ungarn. A Magyar Királyi Földtani Intézet Évkönyve 30/1. Budapest 1934.

= O. KADIĆ-M. MotTL: Az északnyugati Bükk barlanjai (Die Höhen des nordwestlichen Bükkgebirges). Barlangkutatás 17 (1944) 1-111.

= L. KAMINSKÁ: Aurignacké stanice v Čečejovciach (Aurignack-Stationen in Čečejovce). AR 43 (1990) 3-12.

= L' KAMINSKÁ: Plošné retušované hroty zo začiatku mladého paleolitu na východnom Slovensku [Points with flat retouches from the beginning of Upper Palaeolithic in eastern Slovakia]. HCK 21 (1990) 107-116.

= L. KAMINSKÁ: Význam surovinej základne pre mladopaleolitickú spoločnost’ vo východokarpatskej oblasti (L'importance de la matière première pour les communautés du Paléolithique supérieur dans l'espace des Carpathes orientales). SIA 39 (1991) 7-58.

= L. KAminskÁ-J. K. KozŁowski-J. SvobodA: Sequence of the Palaeolithic occupations. In: Pleistocene Environments and Archaeology of the Dzeravá Skala Cave, Lesser Carpathians, Slovakia. Eds: L. Kaminská, J. K. Kozłowski, J. Svoboda. Kraków 2005, 7-58.

I. KARAVAnIĆ: Gornjopaleolitičke kamene i koštane rukotvorine iz špilje Vindije (Les outillages de pierre et d'os du Paléolithique Supérieur de la grotte de Vindija). OA 17 (1994) 53-163.

= Zs. Kasztovszky-K. Biró-A. Markó-V. Dobosi: Cold neutron Prompt Gamma Activation Analysis - a non-destructive method for characterization of high silica content chipped stone tools and raw materials. Archaeometry 50 (2008) 12-29.

= J. KISs: A Darnó hegyi neogén üledékkőzettani vizsgálata (Ore geological studies on the Darnó Hill). FK 88 (1958) 210-214. 
KoZŁOWSKI 1973

KOZŁOWSKI 1999

KoZŁOWSKI et al. 2009

LAPLACE 1970

LENGYEL 2014

LENGYEL-MESTER 2008

MARKÓ 2009a

MARKó 2009b

MARKó 2011

MARKó 2013a

MARKó 2013b

MARKÓ et al. 2003

MAJER 1920

Mester 2000

Mester 2001

Mester 2007

Mester 2014

MotTL 1942

MotTL 1945

NERUdA-NERUdOVÁ 2005

OLIVA 1984

OLIVA 1992

Pelikán (ed.) 2005

PROŠEK 1951

ProšeK 1953
= J. K. KoZŁowsKI: The origin of lithic raw materials used in the Palaeolithic of the Carpathian countries. AAC 13 (1973-1973) 5-19.

= J. K. KozŁowsKI: The evolution of the Balkan Aurignacian. In: Dorothy Garrod and the Progress of the Palaeolithic. Studies in the Prehistoric Archaeology of the Near East and Europe. Eds: W. Davies, R. Charles. Oxford 1999, 97-118.

= J. K. KozŁowski-Zs. Mester-K. Zandler-A. BudeK-T. Kalicki-M. Moskal-Á. Ringer: Le Paléolithique moyen et supérieur de la Hongrie du nord: nouvelles investigation dans la région d'Eger. L'Anthropologie 113 (2009) 399-453.

= G. LAPLACE: L'industrie de Krems Hundssteig et le problème de l'origine des complexes Aurignaciens. In: Frühe Menschen und Umwelt. Teil I: Archäologische Beiträge. Hrsg. von K. Gripp, R. Schütrumpf, H. Schwabedissen. Köln-Wien (1970) 242-297.

= Gy. LENGYEL: Distant connection changes from the Early Gravettian to the Epigravettian in Hungary. In: Modes de contacts et de déplacements au Paléolithique eurasitique. Eds: M. Otte, F. LeBrunRicalens. E.R.A.U.L. 140. Liège 2014, 331-347.

= Gy. Lengyel-Zs. Mester: A new look at the radiocarbon chronology of the Szeletian in Hungary. Eurasian Prehistory 5 (2008) 73-83.

= A. MARKó: Raw material circulation during the Middle Palaeolithic period in northern Hungary. In: Surowce naturalne w Karpatach oraz ich wykorzystanie w pradziejach i wczesnym średniowieczu. Krosno 2009, 107-119.

= A. MARKó: Levéleszközös leletegyüttes Debercsény-Mogyorós lelöhelyröl (Leaf-shaped industry from Debercsény). ArchÉrt 134 (2009) 155-163.

= A. MARKó: A kései középső-paleolitikum csontipara a Kárpát-medencében - The osseous industry of the Late MIddle Palaeolithic period in the Carpathian basin. ArchÉrt 136 (2011) 95-113.

= A. MARKó: Leaf-shaped lithic and osseous tools from old excavated cave sites: demonstrating associations. In: The Sound of Bones. Proceedings of the $8^{\text {th }}$ Meeting of the ICAZ Worked Bone Research Group in Salzburg 2011. Ed: F. Lang. Salzburg 2013, 191-202.

= A. MARKó: On the Middle Palaeolithic industry of the Jankovich cave (northeastern Transdanubia). ArchÉrt 138 (2013) 7-28.

= A. MARKó -K. BIRÓ -Zs. KASZTOVSZKY: Szeletian felsitic porphyry: non-destructive analysis of a classical Palaeolithic raw material. ActaArchHun 54 (2003) 297-314.

= I. MAJER 1920. Az ipolysági aurignacien lelet (Der Aurignacien-Fund von Ipolyság). Barlangkutatás 8 (1920) 13-23.

= Zs. Mester: Apparition du Jankovichien au sud de la Montagne de Bükk (Hongrie). In: A la recherche de 1'Homme Préhistorique. Volume commémoratif de Miklós Gábori et de Veronika Gábori-Csánk. Dir. Zs. Mester, Á. Ringer. E.R.A.U.L. 95. Liège 2000, 247-255.

= Zs. MESTER: Bükki paleolitikus barlangi lelőhelyek régészeti revíziója: három esettanulmány (Révision archéologique de gisements sous grotte Paléolithiques de la montagne be Bükk: trois examlpes). HOMÉ 40 (2001) 21-38.

= Zs. MEster: Pour continuer les investigations sur les gisements classiques en Hongrie : les grottes Szeleta et d'Istállóskő. In: J. Évin (dir.): XXVI Congrès Préhistorique de France. Congrès du Centenaire de la Société préhistorique française, Avignon, 21-25 septembre 2004 : Un siècle de construction du discours scientifique en Préhistoire. Vol. II : «Des idées d'hier ...»(**).Société Préhistorique Française, Paris 2007, 239-248.

= Zs. Mester: Le Szélétien. In: Néanderthal / Cro Magnon: la rencontre. Ed: M. Otte. Arles 2014. 149-188.

= M. MoтTL: Das Aurignacien in Ungarn. Quartär 4 (1942) 82-108.

= M. MotTL: Jelentés az 1936/38. évi ásatások eredményéröl és az ősgerinces osztály müködéséről (Bericht über die Ergebnisse der Grabungen der Jahren 1936/ 38, sowie über die Tätigkeit der Vertebraten-Abteilung der Königlichen Ungarischen Geologischen Anstalt). MÁFIJ 1936-38/4 (1945) $1513 \mathrm{ff}$.

= P. NeRUdA-Z. NerudovÁ: The development of the production of lithic industry in the Early Upper Palaeolithic in Moravia. AR 57 (2005) 263-292.

= M. OLIVA: Technologie výroby a použité suroviny štípané industrie moravského Aurignacienu (La technologie et les matières premières de l'industrie taillée de l'Aurignacien en Moravie). AR 36 (1984) 601-628.

= M. Oliva: The Szeletien occupation of Moravia, Slovakia and Bohemia. Časopis Moravského Musea, Vědy společenské 77 (1992) 35-58.

= P. PELIKÁn (ed.): A Bükk hegység földtana (Geology of the Bükk Mountains). Budapest 2005.

= Fr. ProšEK: Výzkum jeskynĕ Dzeravé scaly v Malých Karpatech (Fouilles de la grotte «Dzeravá skala» dans les Petit Karpathes en Slovaquie). AR 3 (1951) 293-298.

= Fr. ProšEK: Szeletian na Slovensku (Le Szeletien en Slovaquie). SlA 1 (1953) 133-194. 
RIgAUD-LUCAS 2006

RINGER 1983

RINGER 2002

RINGER-MESTER 2000

RINGER-SZOLYÁK 2004

SAÁD 1927

SAÁD 1929

SIMÁN 1990

SIMÁN 1993

SIMÁN 1996

SiMÁN 2006

SiTLIVY et al 2012

Svoboda 2006

SvobodA-SimÁn 1989

TAKÁCS-BIRÓ 1986

TEYSSANDIER 2006

TeyssANDIER-Liolios 2008

UsIK 2008

VALOCH 1968

VÉRTES 1951

VÉRTES 1955

VÉRTES $1956 a$

VÉRTES $1956 b$

VÉRTES 1957

VÉRTES 1961

VÉRTES 1965
= J.-PH. Rigaud-G. LuCAS: The first Aurignacian technocomplexes in Europe: a revision of the Bachokirian. In: Towards a Definition of the Aurignacian - Proceedings of the Symposium held in Lisbon, Portugal, June 25-30, 2002. Eds: O. Bar-Yosef, J. Zilhão. Trabalhos de Arqueologia 45. Lisboa 2006, 277-287.

= Á. RINGER: Bábonyien - Eine mittelpaläolithische Blattwerkzeugindustrie in Nordostungarn. DissArch II/11. Budapest 1983.

= Á. RINGER: The new image of the Szeleta and Istállós-kő caves in the Bükk Mountains: a revision project between 1999-2002. Praehistoria 3 (2002) 47-52

= Á. RingeR-Zs. Mester: Résultats de la revision de la Grotte Szeleta entreprise en 1999 et 2000. Anthropologie (Brno) 38/3 (2000) 261-270.

= Á. Ringer-P. SzOLYÁK: A Szeleta-barlang tüzhelyeinek és paleolit leleteinek topográfiai és sztratigráfiai eloszlása - Adalékok a leletegyüttes újraértékeléséhez (The topographic and stratigraphic distribution of the Palaeolithic hearth and finds in the Szeleta cave - Contribution to the re-interpretation of the assemblages). HOMÉ 43 (2004) 13-32.

= A. SAÁD: Die Ergebnisse der Ausgrabungen in der Istállosköer Höhle im Jahre 1927. Die Eiszeit 4 (1927) 97-98.

= A. SAÁD: A Bükk hegységben végzett újabb kutatások eredményei (Über die Resultate der neueren Ausgrabungen im Bükkgebirge). ArchÉrt 43 (1929) 238-247, 375.

= K. SIMÁN: Considerations on the "Szeletian Unity". In: Feuilles de pierre - Les industries a pointes foliacées du Paléolithic superieur Européen. Études et recherches archéologiques de l’Université de Liege 42. Liège 1990, 189-198.

= K. SiMÁN: Őskőkori leletek Nógrád megyében (Fünde aus der Vorzeit im Komitat Nógrád). NMMÉ 18 (1993) 247-254.

= K. SIMÁN: Palaeolithic in north-east Hungary. In: Palaeolithic in the Middle Danube Region - Anniversary volume to Bohuslav Klíma. Ed. J. Svoboda. Spisy Archeologického Ústavu AV ČR v Brně. 5. Brno 1996, 39-48

= K. SimÁn: Tradition, laziness - curiosity, innovation. In: Stone Age - Mining Age. Eds. G. Körlin, G. Weissgerber. Der Anschnitt. Beiheft 19 Bochum 2006, 455-464.

= V. Sitlivy-V. Chabai-M. Anghelinu-Th. Uthmeier-H. Kels-A. Hilgers-Ch. Schmidt-L. NiţĂ-I. BĂLteAn-A. Veselsky-Th. Hauck: The earliest Aurignacian in Romania: New investigations at the open air site of Româneşti-Dumbrăviţa I (Banat). Quartär 59 (2012) 85-130.

$=$ J. SvobodA: The Aurignacian and after: chronology, geography and cultural taxonomy in the Middle Danube region. In: Towards a Definition of the Aurignacian - Proceedings of the Symposium held in Lisbon, Portugal, June 25-30, 2002. Eds: O. Bar-Yosef, J. Zilhão. Trabalhos de Arqueologia 45. Lisboa 2006, 259-274

= J. Svoboda-K. SimÁn: The Middle-Upper Palaeolithic transition in southeastern Central Europe (Czechoslovakia and Hungary). Journal of World Prehistory 3/3 (1989) 283-322.

= K. TAKÁCS-BIRÓ: The raw material stock for chipped stone artefacts in the Northern Mid-mountains Tertiary in Hungary. In: Papers for the $1^{\text {st }}$ International Conference on Prehistoric Flint Mining and Lithic Raw Material Identification in the Carpathian Basin. Ed. K. T. Biró. Budapest 1986, 183-195.

$=$ N. TEYSSANDIER: Questioning the first Aurignacian: mono or multi cultural phenomenon during the formation of the Upper Palaeolithic in Central Europe and the Balkans. Anthropologie (Brno) 44/1 (2006) 9-29.

= N. TEXSSANDIER-D. Liolios: Le concept d'Aurignacien: entre rupture préhistorique et obstacle épistémologique. BSPF 105 (2008) 737-747.

= V. UsIK: Verhnij paleolit Zakarpat'ja: hronologija I kul'turnaja prinadlezhnost'orin'jaka Beregovo I (The Upper Palaeolithic of Transcarpathian: chronology and cultural determination Of Aurignacian of Beregovo I site). Materiali I doslidzhennja z arheologii Prikarpattja i Volini 12 (2008) 49-67.

$=\mathrm{K}$. VAlOCH: Evolution of the Palaeolithic in Central and Eastern Europe. Current Anthropologie 9 (1965) 351-390.

= L. VÉRTES: Novye raskopki v peschere na Istallosko. ActaArchHung 1 (1951) 15-34.

= L. VÉRTES: Neuere Ausgrabungen und paläolithische Funde in der Höhle von Istállóskő. ActaArchHung 5 (1955) 111-131.

= L. VÉRTES: Gruppen des Aurignacien in Ungarn. ArchA 19/20 (1956) 15-27.

= L. VÉRTES: Problematika szeletienu / Problemkreis des Szeletien. SlA 4 (1956) 318-340.

= L. VÉRTES: Az első hazai anyagon végzett rádiokarbon-vizsgálat (Ergebnis der erste $\mathrm{C}^{14}$-Untersuchung an ungarichen Material). ArchÉrt 84 (1957) 222.

= L. VÉRTES: Das Verhältnis des Aurignacien zum Szeletien in der Istállóskőer Höhle. Germania 39/3-4 (1961) 295-298.

= L. VÉRTES: Az őskőkor és az átmeneti kőkor emlékei Magyarországon (Records of the Palaeolithic and Mesolithic in Hungary). A magyar régészet kézikönyve 1. Budapest 1965. 
VÉRTES 1968

VÉRTES-TÓTH 1963

VÉRTES-DE VRIES 1959

VOGEL-WATERBOLK 1963

VÖRÖS 2003-2004

WILCZYÑSKI 2009

ZILHÃO 2009
= L. VÉRTES: Szeleta-Symposium in Ungarn, 4.-11. September 1966. Quartär 19 (1968) 381-390.

= L. VÉRTES-L. TÓTH: Der Gebrauch des Glasigen Quartzporphyrs im Paläolithikum des Bükk-Gebirges. ActaArchHung 15 (1963) 3-10.

= L. VÉRTES-H. DE VRIES: Az Istállóskői barlang aurignaci II kultúrájának rádiokarbon kormeghatározása (Radiokarbonbestimmung des Aurignacien II aus der Istállóskő Höhle). ArchÉrt 86 (1959) 195.

= J. C. VOGEL-H. T. WATERBOLK: Groningen radiocarbon dates IV. Radiocarbon 5, 163-202.

= I. VöRös: Stratigraphy and biostratigraphy of Istállóskő cave. Praehistoria 4-5 (2003-2004) 33-76.

= J. WILCZYÑSKI: Targowisko - A new Late Glacial site in Southern Poland. Eurasian Prehistory 6 (2009): 95-118.

$=\mathrm{J}$. ZILHÃo: Szeletian, not Aurignacian: A review of the chronology and cultural associations of the Vindija G1 Neandertals. In: Sourcebook of Paleolithic Transitions. Eds. M. Camps, P. Chauhan. DOI 10.1007/978-0-387-76487-0_27, Springer Science (2009) 407-426. 